\title{
Caribbean Growth in an International Perspective: The Role of Tourism and Size
}

Nita Thacker, Sebastian Acevedo, and Roberto Perrelli 


\title{
IMF Working Paper
}

Western Hemisphere Department

\section{Caribbean Growth in an International Perspective: The Role of Tourism and Size \\ Prepared by Nita Thacker, Sebastian Acevedo, and Roberto Perrelli* \\ Authorized for distribution by George Tsibouris}

September 2012

\section{This Working Paper should not be reported as representing the views of the IMF. The views expressed in this Working Paper are those of the author(s) and do not necessarily represent those of the IMF or IMF policy. Working Papers describe research in progress by the author(s) and are published to elicit comments and to further debate.}

\begin{abstract}
After earlier success, growth performance in most Caribbean countries has been disappointing since the early 1990s. With slower growth, output has fallen behind that of relevant comparator countries. This paper analyzes the growth experience of the Caribbean countries from a cross country perspective. Three findings stand out. First, the slowdown in growth is explained more by a decline in productivity rather than a lack of investment. Second, tourism has been a significant contributor to higher growth (through both capital accumulation and productivity) and lower output volatility, and in many countries there is scope for further expansion of this sector. Third, the small size and the fact that most of these countries are islands have limited growth. Policies aimed at improving productivity, further development of the tourism sector, and regional integration could pay dividends in terms of higher growth in the region.
\end{abstract}

JEL Classification Numbers: C33, O40, O54.

Keywords: Caribbean, tourism, size, growth, productivity.

Authors' E-Mail Addresses: nthacker@,imf.org; sacevedomejia@imf.org; rperrelli@,imf.org.

\footnotetext{
* We would like to thank Rodrigo Valdés, Therese Turner-Jones, Wendell Samuel, Garth Nicholls and Charles Amo-Yartey and other colleagues at the IMF's Western Hemisphere Department for helpful comments and suggestions. The usual disclaimer applies.
} 


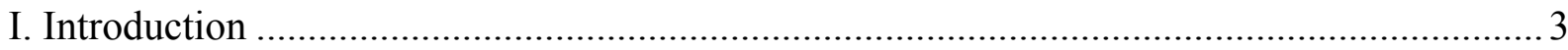

II. Catching Up or Falling Behind? A Caribbean Tale ......................................................... 5

III. Accounting for Growth in the Caribbean................................................................ 7

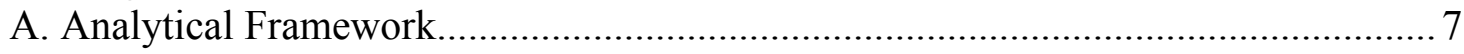

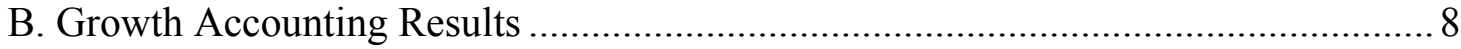

C. Level Accounting Results ..................................................................... 12

IV. The Tourism and Growth Nexus in the Caribbean ..................................................... 13

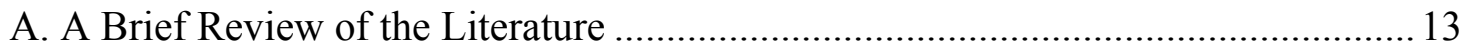

B. The Proposed Econometric Approach................................................................. 14

C. The Impact of Tourism on Growth Levels...................................................... 15

D. The Impact of Tourism on Growth Volatility ........................................................ 17

E. Tourism, Size and Growth Accounting ................................................................ 18

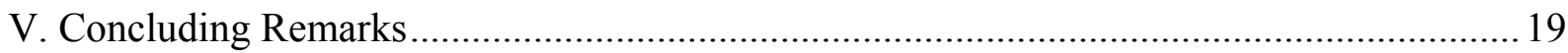

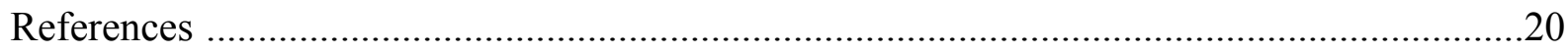

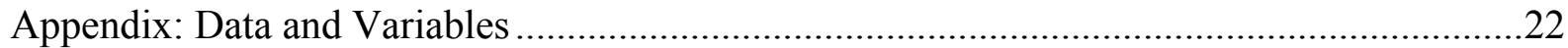




\section{INTRODUCTION}

Caribbean countries have experienced low growth since the 1980s, with the current global slowdown derailing the feeble recovery of the early 2000s. ${ }^{1}$ The region has been buffeted by a series of adverse exogenous shocks over time, including the erosion of trade preferences; the decline in official foreign assistance; frequent natural disasters; and recessions in source countries that drive tourism and FDI in the region. The recent global slowdown has exacerbated the already declining trend in growth. As a result, average growth has dropped from 3.0 percent in the 1970 s to 2.7 percent in the $2000 \mathrm{~s},{ }^{2}$ although there is significant heterogeneity in growth performance across these countries. ${ }^{3}$

The objective of this paper is to analyze the growth performance of the Caribbean economies over the last four decades in an attempt to understand the underlying trends and answer the following questions (i) why has growth slowed down? (ii) what have been the major constraints on growth, i.e., is it a question of low capital accumulation or is it low productivity? (iii) has tourism been an important driver of growth and is there scope for additional growth from tourism? and finally (iv) is growth constrained by the small size and the island nature of these countries?

When referring to the island nature of small countries we consider the effects of higher transportation costs for basic inputs and exports, the increased difficulty in access to bigger markets, the concentration of economic activity in a small number of sectors that increases the vulnerability to external shocks, and the reduced market size of the economy, whose negative effect is compounded by the physical disconnect from other markets. ${ }^{4}$ To clarify the point, lets take the case of Hong Kong and Singapore; albeit technically small islands, they are not considered as such in the paper due to their close proximity and access to large continental markets. Their cultural and commercial ties and geographical proximity to big markets allows them to work as entrepots bridging markets abroad with regional economies in ways which are not possible for other small islands.

\footnotetext{
${ }^{1}$ The countries referred here as the Caribbean are Antigua and Barbuda, The Bahamas, Barbados, Belize, Dominica, Grenada, Guyana, Jamaica, St. Kitts and Nevis, St. Lucia, St. Vincent and the Grenadines, Suriname, and Trinidad and Tobago. The sampled countries share some common factors, most have a large tourism sector, use a common language (English), and share a former colonial relationship with the United Kingdom. Most also became independent in the 1960s and 1970s and six of them are members of the Eastern Caribbean Currency Union (ECCU), with a common central bank and a currency that has been pegged to the U.S. dollar since 1976. The ECCU members are Antigua and Barbuda, Dominica, Grenada, St. Kitts and Nevis, St. Lucia and St. Vincent and the Grenadines. They are also members of the Caribbean Common Market (CARICOM).

${ }^{2}$ PPP weighted average of the real GDP growth rates.

${ }^{3}$ For a brief presentation of the different performances in the Caribbean see Thacker and Acevedo (2010).

${ }^{4}$ On this last point, it is important to note that Alesina, Spolaore and Wacziarg (2005) emphasize that the market size does not need to match the political borders of a country if there is sufficient trade. However, we would argue that even in the presence of trade, small island economies do not fully enjoy the benefits from positive externalities in the accumulation of human capital, transmission of knowledge, or increasing returns to scale because of the increased difficulty in trans-border interactions with other markets.
} 
While there are some studies that have tried to investigate the growth performance of Caribbean countries; ${ }^{5}$ there is very little analysis, if any, of the systematic role of tourism in these economies, the prospects of future growth from tourism, and the constraints placed by their small size. With this in mind, we start with a growth accounting framework to investigate the contributions of capital accumulation and total factor productivity (TFP) to economic growth and in particular, to understand their role in explaining the growth decline. We also use standard regression analysis to understand the determinants of growth in the past four decades. To account for some of the unique characterstics of these small islands, we augment our regression models to include the role of the tourism sector, the island nature and the relatively small size of these economies, and investigate to what extent these factors have influenced growth. In the estimations we also study the effects that torusim and size have on productivity and factor accumulation, searching for a link between tourism, size, TFP and output growth.

Our results indicate that: (i) the slowdown in growth is largely explained by a decline in productivity growth rather than low capital accumulation; (ii) tourism has had an important positive impact on growth both through capital accumlation and productivity; and (iii) size and the island nature are major constraints on growth. In particular, the analysis suggests that tourism remains a viable strategy for most of the Caribbean countries, and that there is still room for this sector to expand and enhance growth and productivity.

The paper is organized as follows. Section II presents some stylized facts about growth in the Caribbean since the 1970s. Section III uses the growth and level accounting frameworks to assess the extent to which growth has been driven by factor accumulation versus gains in total factor productivity. Section IV reviews the determinants of long-term growth, volatility, and TFP using regression analysis, including tourism and variables that represent the size and island nature of these countries. Section V draws some policy conclusions based on the results of the study.

\footnotetext{
${ }^{5}$ Sosa and Cashin (2009), Mlachila, Cashin and Haines (2010), and Cashin (2006).
} 


\section{Catching Up or Falling Behind? A Caribbean Tale}

The following salient points evolve from an analysis of agggregate growth figures over the last 40 years:

Average growth has been relatively low among Caribbean countries compared to their peers in emerging market and developing countries. Growth has averaged 2.2 percent according to purchasing power parity (PPP)-based GDP weights (or 3.4 percent based on a simple regional average), compared with 5.1 percent for emerging market economies and developing countries. Moreover, not only have they lost ground vis-à-vis emerging and developing economies, but also with respect to other small islands as depicted in Figure 1. ${ }^{6}$ That said, the Caribbean region fared better than Latin America (LA) from the mid 1990s until 2003.

However, with the commodity export boom in Latin America since the early 2000s, growth in LA countries outpaced the

GDP Growth and Volatility

(Based on real GDP growth rates (PPP) 1971-2009)

\begin{tabular}{lcccc}
\hline Countries & Countries & $\begin{array}{c}\text { Average } \\
\text { Growth }\end{array}$ & $\begin{array}{c}\text { Average } \\
\text { Std. Dev. }\end{array}$ & $\begin{array}{c}\text { Frequency } \\
\text { of Growth } \\
\text { Crashes }\end{array}$ \\
\hline Caribbean (simple average) & 13 & 3.4 & 4.7 & 4.5 \\
Caribbean & 13 & 2.2 & 4.7 & 4.5 \\
$\quad$ ECCU & 6 & 4.3 & 4.2 & 3.0 \\
$\quad$ Non-ECCU Caribbean & 7 & 2.1 & 5.0 & 5.9 \\
$\quad$ Non-Caribbean emerging & 136 & 5.1 & 6.8 & 6.2 \\
and developing economies & 17 & 3.4 & 4.5 & 4.5 \\
Latin America & 18 & 4.3 & 5.6 & 4.2 \\
Non-Caribbean small islands & 31 & 3.7 & 5.0 & 5.0 \\
Countries with comparable & 31 & & &
\end{tabular}

Sources: World Economic Outlook; and IMF staff calculations.

1 Share of years (in percent) with grow th low er than -5.1 percent ( $w$ hich corresponds to the 5th percentile of all country/years grow th).

${ }^{2}$ Countries that are $w$ ithin \pm half of a standard deviation of the average real GDP per capita of the Caribbean countries in 1970. They include Albania, Algeria, Angola, Bolivia, Brazil Bulgaria, Chile, China,P.R., Hong Kong SAR, Colombia, Costa Rica, Cyprus, Ecuador, 日 Salvador, Guatemala, Hungary, Iran, I.R. of, Malta, Mexico, Nicaragua, Panama, Peru, Poland, Portugal, Romania, Seychelles, Singapore, South Africa, Taiw an Province of China, Turkey, Uruguay, and Vanuatu.

Note: Figures for country groups are PPP-w eighted averages.

Caribbean. More recently, this wedge in growth rates has increased with FDI and tourism in the Caribbean region taking a hit from the global financial and economic crisis, while the LA countries have benefited from rising commodity prices and large capital inflows.

\footnotetext{
${ }^{6}$ For a list of which countries are considered small islands in this paper please see the Appendix.
} 
Figure 1. Caribbean: Ratio of Per capita GDP (PPP) to Relevant Comparators, 1970-2009

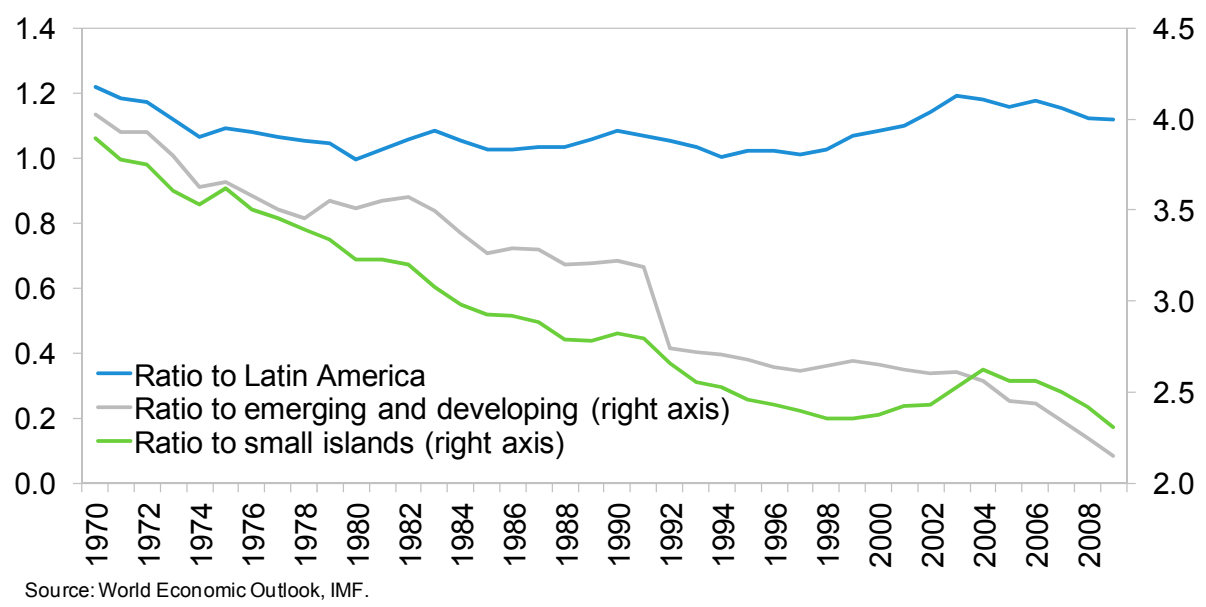

Furthermore, there is substantial heterogeneity across the Caribbean economies. For instance, ECCU economies grew vary rapidly during the 1970s and 1980s driven by an expansion of agricultural exports (mainly bananas and sugar) under preferential trade arrangements, large aid inflows that followed independence from the United Kingdom, and an initial spurt from tourism. However, there was a marked slowdown after that period, reflecting largely the structural shifts in production caused by the dismantling of trade preferences, a decline in aid inflow, and exogenous shocks. Also, countries that made an early switch to tourism and/or specialized in financial sector services - such as Antigua and Barbuda, The Bahamas, and Barbados - were able to partially offset the impact of the decline in the agriculture sector. As a result, those countries remain with a level of output per capita that is much higher than those in the rest of the region. On the other hand, commodity exporters such as Guyana, Trinidad and Tobago and Suriname, have made a dramatic recovery since the late 1980 s, reflecting higher commodity export prices as well as increased production of minerals and fossil fuels.

On the positive side, growth in the Caribben has been less volatile than in other regions. Despite the trade openness of their economies and high exposure to natural disasters, the volatility of output growth in the Caribbean over the 40 -year period was 4.7 compared to 5.0 for comparator countries and much lower than for emerging and developing market countries (6.8). This is true irrespective of whether volatility is measured as the standard deviation of GDP growth, or based on the frequency of growth crashes (events of large drops in activity). However, the non ECCU Caribbean countries (which includes some commodity exporters like Trinidad and Tobago and Suriname) have more volatile growth than the ECCU countries. This suggests that the dominance of the service sector and remittances are likely to have helped offset, in part, the volatility from commodity prices and natural disasters. 


\section{AcCounting For Growth In The CARIBbean}

The analysis of the sources of growth dates back to the 1950s with the seminal work of Solow (1957). Solow first decomposed output growth into the growth of labor, capital and a residual - the "Solow residual" - and interpreted it as a measure of the contribution of technological change to growth. In the 1960s and 1970s, the literature was extended to include both the quantity and quality of labor and capital. ${ }^{7}$ More recently, Barro and Lee (1994), Lee (2005) and Loayza, Fajnzylber and Calderon (2005) applied this analysis to cross-sections of countries. While some of these studies covers selective Caribbean countries, there is little work done that encompasses all the Caribbean, particularly the countries in the Eastern Caribbean Currency Union.

We use this growth accounting framework to assess the extent to which observed output growth in the Caribbean can be explained by factor accumulation or by total factor productivity (TFP) gains. However, as recognized in the literature, this framework has some important limitations. Most importantly, the TFP component is measured as an unexplained residual and therefore picks up measurement errors in the data, including the difficulty of accounting for improvements in the quality and composition of physical and human capital, which in the present sample could be significant. Other limitations of the framework include its reliance on the assumptions of complete markets and constant returns to scale. It also does not explain TFP changes from one period to another. Notwithstanding these caveats, this framework remains an important tool for policymakers to help diagnose the contribution of different factors and the constraints to growth, as well as the design of policies to enhance it.

\section{A. Analytical Framework}

We use the conventional Cobb-Douglas production function with constant returns to scale to calculate the contribution of each factor to growth. Due to the paucity of data on educational attainment for some Caribbean countries, we use a basic production function that includes only capital and labor as factor inputs, leaving out the contribution of human capital:

$$
Y=A K^{\alpha} L^{1-\alpha}
$$

where, $Y$ is aggregate output, $A$ is total factor productivity, $K$ is the physical capital stock, $L$ is the unit of labor, and $\alpha$ is the factor-income share of capital. Taking logs, differentiating with respect to time, and expressing the variables as growth rates give us: ${ }^{8}$

\footnotetext{
${ }^{7}$ Denison (1962), Jorgenson and Griliches (1967) and Denison, Jorgenson and Griliches (1972).

${ }^{8}$ The dots over the variables denote derivatives with respect to time.
} 


$$
\frac{\dot{Y}}{Y}=\frac{\dot{A}}{A}+\alpha \frac{\dot{K}}{K}+(1-\alpha) \frac{\dot{L}}{L}
$$

The contribution of each factor is then calculated as its growth rate multiplied by its share, with TFP as the residual. Following the literature in this area (Lee, 2005), we assume the share of capital $\alpha=0.35$, constant and equal across countries. ${ }^{9}$

To ensure comparability of data across countries, we use the Penn World Tables (PWT 6.3 of Heston et al. (2009)). As in Lee (2005), the working age population, i.e., population between the ages of 15-64, is used as a measure of the size of the labor force. The physical capital stock is constructed using investment data from the PWT and applying the perpetual inventory method. Average depreciation is assumed to be 6 percent per year over the period. However, given that the region suffers from the recurrence of natural disasters that may destroy the capital stock, we adjusted it for years in which there were major hurricanes that inflicted considerable damage to the islands, so the transition equation for the capital stock is:

$$
K_{t+1}=(1-\delta) \cdot\left(K_{t}-H D_{t}\right)+I_{t}
$$

where $H D_{t}$ denotes hurricane damages to the capital stock at time $t$.

The data on hurricane damages comes from the Emergency Disaster Database (EM-DAT) that records the estimated damages of natural disasters in current US dollars. We use this information in the perpetual inventory method to adjust the capital stock in every year when there was a hurricane with recorded damages as in equation (3). While the EM-DAT's data are not exhaustive, the adjustments to the capital stock help improve the accuracy of TFP's contribution to growth. ${ }^{10}$ Without adjusting for the hurricane damages TFP accounted only for 22.7 percent of total Caribbean growth from 1970 to 2007, while the adjustment increases the contribution of TFP to growth by 2.5 percentage points to 25.2 percent. In some cases the contribution is even higher, e.g., in the case of Dominica, accounting for the effects of hurricanes increases the contribution of TFP to growth by more than 10 percentage points.

\section{B. Growth Accounting Results}

Our results indicate that TFP explains the bulk of the variation in economic growth in the Caribbean (see Tables 1 and 2, and Figures 2 and 3). However, there are significant differences at the country level. TFP growth was the strongest in the 1970s in Dominica, St. Kitts and Nevis, and St. Lucia. In Dominica, TFP growth has since declined and in recent years, growth in TFP has been negative. Negative TFP growth is hard to interpret because it implies "a technical regress" Barro (1998), which might simply reflect a drop in the

\footnotetext{
${ }^{9}$ Using different values for $\alpha$ (for example, $\alpha=0.30$ to 0.45 ) makes little difference to the overall results.

${ }^{10}$ Without the adjustment to capital due to the hurricanes damages, the contribution of capital to growth is overstated. Because of the paucity of employment data in the Caribbean, it is possible that TFP is underestimated in years where there are natural disasters, since we cannot account for possible increases in unemployment.
} 
efficiency with which the other factors of production are used either because other complementary circumstances have changed or due to bad policies and weak institutions. That said, St. Kitts and Nevis has been able to reverse the declining trend in productivity, and its TFP has risen since 2000. Other countries that have done so are Antigua and Barbuda and St Vincent and the Grenadines.

Some factors that may have contributed to higher productivity are relatively stronger institutions and policies geared to improve efficiency gains. For instance, these countries have tried to find a niche for their products, mainly in high-end tourism services, which may explain partly the improvement in productivity. ${ }^{11}$ However, in the last decades, productivity growth declined noticeably in the region, perhaps reflecting inadequate infrastructure and absence of complementary skill factors to capital. This lower productivity growth has led to a marked decline in output growth in spite of investment remaining relatively robust, as suggested by the large contribution of capital accumulation.

Among economies like Trinidad and Tobago, Suriname and Guyana, modest increases in investment have been accompanied by a jump in productivity, helping the region to generate higher growth. This can be largely explained in terms of the discovery of natural resources in these countries in the mid-1990s and the generally high commodity prices since then which have contributed to growth and outpaced the decline from agriculture. Meanwhile, in most tourism based economies, including Barbados and Belize, the contribution of TFP has been much more marginal - both on average and in explaining growth swings. In these countries, the contribution of capital formation also seems modest, particularly when compared with world averages.

It is important to note that the decline in TFP since the 1990's is partially a result of the transition from a labor intensive agricultural sector to a more capital intensive tourism sector. Given that the data do not allow us to control for the effect of unemployment in the labor input, this effect is captured by the TFP component. ${ }^{12}$ For instance, the secular increase in unemployment in some Caribbean countries following the decline in trade preferences in the 1990's, as well as the increase in capital accumulation related to tourism investment, may jointly explain the decline in TFP observed in our results due to our measure of the labor input. However, it must be emphasized that over a sufficiently long period of time, any bias in the average TFP contribution to growth disappears. The overestimation of TFP in periods of higher unemployment cancels out with its underestimation in periods of lower unemployment.

\footnotetext{
${ }^{11}$ In the next section we show that high-end tourism has a positive effect on productivity. But, we also show that the volume of arrivals has a bigger effect on productivity, and could be perhaps a more beneficial strategy.

${ }^{12}$ By using the labor force as a measure of the labor input, we are assuming that labor is close to full employment. Unfortunately, the paucity of data precludes us from using a better measure for the labor input.
} 
Figure 2. ECCU: Contributions to Growth, 1970-2007

(In percent, adjusted for the effect of hurricanes on capital)
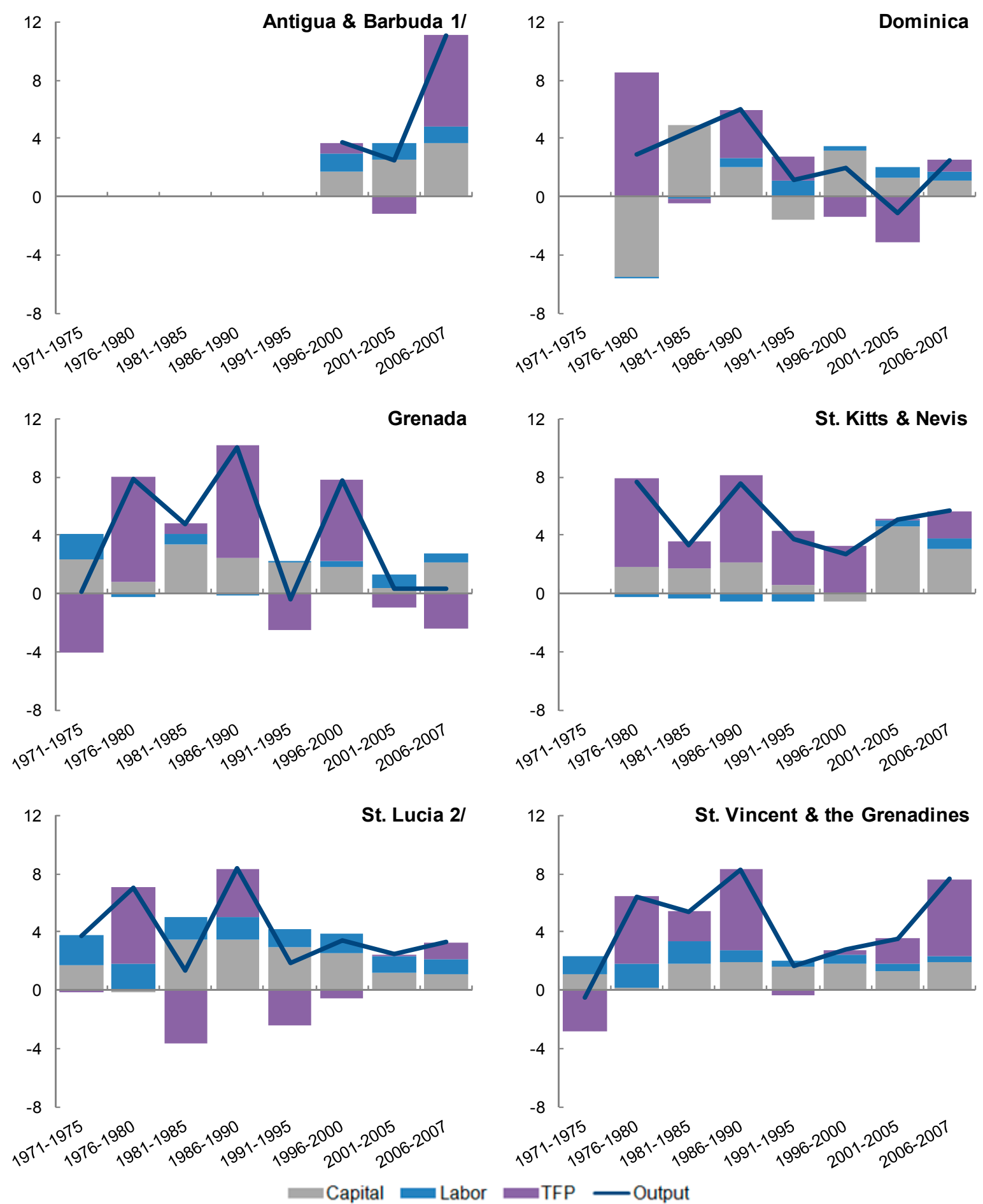

Sources: Emergency Disaster Database (EM-DAT), CRED (2010); Heston, Summers, and Aten (2009); and IMF staff calculations.

1/ The Penn World Tables version 6.3 only has available data for Antigua and Barbuda since 1996.

2/ The data for St. Lucia omits EM-DAT's entry of US $\$ 1$ billion damages in 1988, which is erroneous. 
Figure 3. Other Caribbean: Contributions to Growth, 1970-2007

(In percent, adjusted for the effect of hurricanes on capital)
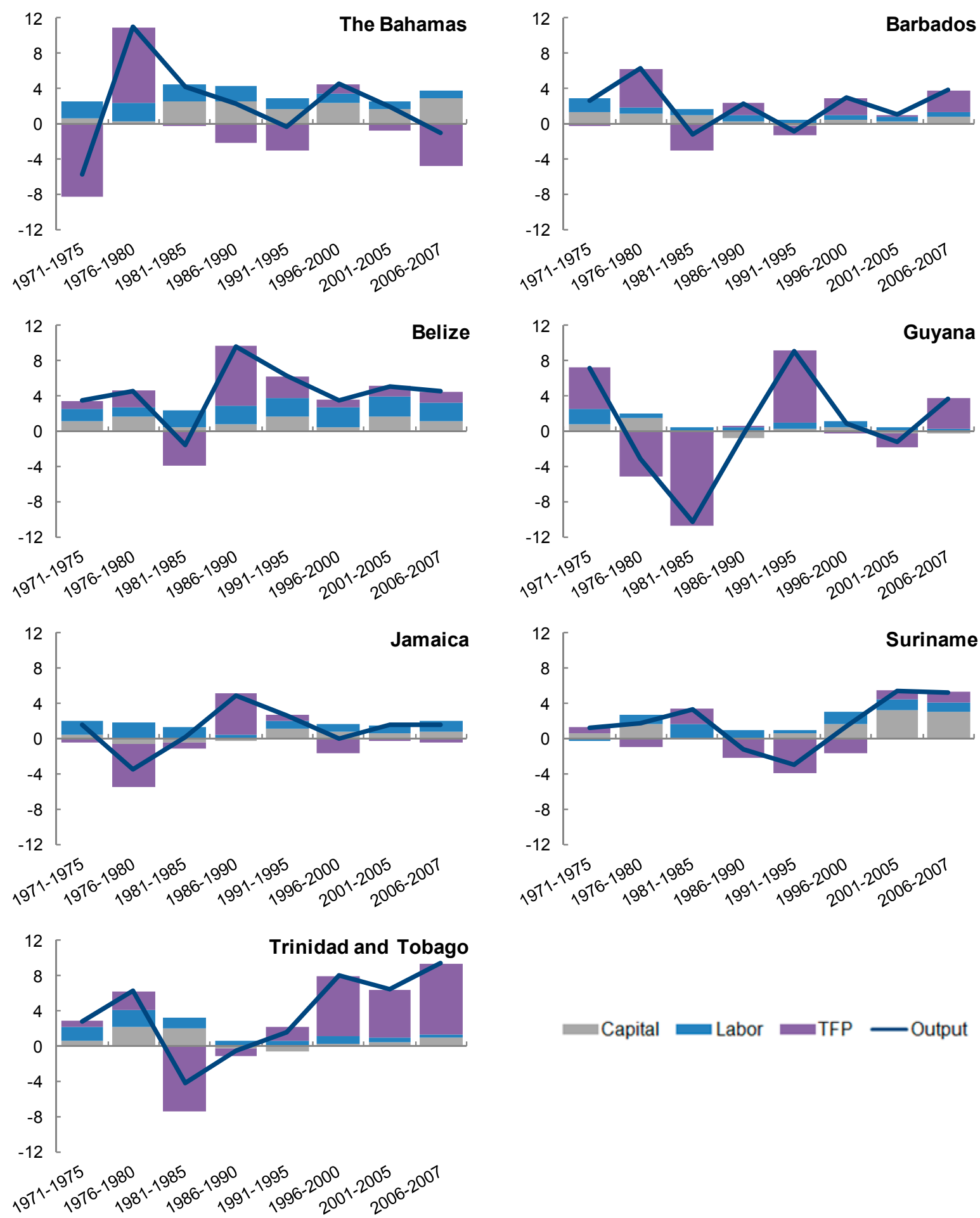

Capital Labor $=$ TFP Output

Sources: Emergency Disaster Database (EM-DAT), CRED (2010); Heston, Summers, and Aten (2009); and IMF staff calculations. 


\section{Level Accounting Results}

Another way to analyze the contribution of TFP is by comparing the ratio of output per worker between two countries. This allows us to answer another and perhaps more interesting question about how variations in productivity and variations in factor accumulation contribute to variations in output across countries. For this purpose, we use the level accounting methodology of Hall and Jones (1999) which transforms equation (1) into per worker units of output and capital (denoted by lower-case letters) and compares the difference in output per worker between countries $i$ and $j$, by decomposing it into the difference between their capital-labor ratios and the TFP ratios:

$$
\frac{y_{i}}{y_{j}}=\left(\frac{A_{i}}{A_{j}}\right) \cdot\left(\frac{k_{i}}{k_{j}}\right)^{\alpha} \text {. }
$$

Tables 3 and 4 present the output and capital per worker and the productivity levels of Caribbean countries with respect to Barbados - the benchmark country chosen for this exercise given that it has one of the highest output per capita among the Caribbean countries included in this study. ${ }^{13}$

The results suggest two important developments: first that since the 1970s, in general many of the countries have seen an improvement in both the output per worker and productivity and have been catching up with Barbados. For instance, with the exception of St. Lucia, all other ECCU countries show an improvement in productivity from 1970 to 2007. Among the other Caribbean countries, Belize and Trinidad and Tobago show considerable improvements in productivity vis-à-vis Barbados. Second, there are still sizable gaps between Barbados and some Caribbean countries. Dominica, Guyana and St. Vincent and the Grenadines have productivity levels at or below 50 percent of the level in Barbados. This in turn is translated into low output per capita levels with respect to Barbados and the rest of the region.

The level accounting approach is appealing because it hints on the best way to increase output levels to that of another country. For example, Antigua and Barbuda has a productivity level above the one for Barbados in 2007. Antigua could outperform Barbados in output per capita if it was not for Antigua's low level of capital per worker (52 percent of Barbados' level), that is, the exercise suggests that Antigua and Barbuda could catch up with Barbados' output level by focusing on increasing its capital per worker ratio to Barbados' level. On the other side, Grenada shows the opposite problem, it has a very high stock of capital but productivity is only 61 percent of Barbados, so their output is about two thirds of Barbados. Hence, this suggests that productivity improvements would be more beneficial than further accumulation of capital.

\footnotetext{
${ }^{13}$ While The Bahamas has the highest output per capita in the region, Barbados is a more diversified economy and is less dependent on the U.S. as a source of tourism exports, making it a better benchmark country for the rest of the Caribbean.
} 
To further illustrate the importance of productivity gains, we calculate what the level of output per worker would be if we assumed the Caribbean achieves the level of productivity (or the level of capital per worker) of the U.S. (see Tables 5 and 6). If the region managed to raise productivity to U.S. levels, output per worker could be doubled, with the ECCU, Guyana, Suriname and Jamaica benefiting somewhat more than the rest of the Caribbean economies. Output would also increase if capital per worker were to reach U.S. levels, although the gain would be far less spectacular. This suggests that although a further boost in investment could enhance output, benefits from raising productivity would be much greater.

The declining trend in productivity ratios to the U.S., evident in Tables 5 and 6 is troubling. Instead of converging over time towards productivity levels in line with those of advanced economies, the Caribbean has been quickly drifting away. And given the critical importance of productivity in achieving higher output growth it is imperative to reverse the trend if the Caribbean region is eventually going to catch-up with advanced economies' output levels.

\section{The Tourism and Growth NeXus In The CARIBbean}

Most Caribbean economies went through a transformation in the 1960s and 1970s, moving from dependence on agriculture (often monoculture) to dependence on tourism. The consequences of such a strong dependence on a single sector are not obvious. An expansion of the tourism sector could have either a positive or negative impact on long-term growth. On the positive side, the specialization could raise output levels and productivity in the initial years, and thereafter the sector could be a locus of ongoing growth. On the negative side, specialization in tourism could mean lower productivity growth in the future - on the critical assumption that other sectors (e.g., manufacturing) are more prone to stimulate productivity growth (IMF, 2011, pp. 41-46).

In this section we use the standard growth model, augmented by various measures of tourism and size, to investigate if they played a statistically significant role in determining long-term growth in small islands and tourism-dependent economies, with special focus on the Caribbean region. We not only study the effects on growth, but we also look at the effects of tourism and size on output volatility, and on productivity and capital accumulation. The latter, allows us to bridge the results of the growth accounting exercise with the econometric methodology employed in this section.

\section{A. A Brief Review of the Literature}

Few papers have tried to measure the impact of tourism on growth, with some mixed results. The results seem to be highly influenced by the econometric technique and the sample composition used by the authors. For instance, Eugenio-Martín, Martín and Scarpa (2004) use the Arellano-Bond (1991) dynamic panel approach with annual data to show that in 21 Latin American and Caribbean ${ }^{14}$ countries tourism has a positive and significant impact on growth, particularly for low and middle income countries. On the other hand, Sequeira and Campos (2007), using random and fixed effects panels for quinquenial data from 1980-1999,

\footnotetext{
${ }^{14}$ None of the ECCU countries, the Bahamas, Barbados, Belize or Suriname are included in the sample used by those authors.
} 
find that tourism specialization has no statistically positive impact on growth. Sequeira and Nunes (2008), using a system GMM dynamic panel approach (the Blundell and Bond (1998) estimator) show that tourism has a positive impact on growth both in a broad sample of countries and in poor countries, but it finds no evidence of tourism being more important for small countries. Finally, Arezki, Cherif and Piotrowski (2009) use a cross-section of countries for the period 1980-2002, and instruments based on the number of UNESCO World Heritage List, to find a positive effect of tourism exports on growth.

A limitation of these papers is that for the most part they exclude small island countries due to the paucity of data. This is particularly important in our study because most of the small Caribbean islands are highly dependent on tourism. Hence we went to great lengths to assure the broadest coverage possible of small island economies in our regression analysis. In the regressions to be presented next, we use a panel data of 154 countries covering a period of 29 years to investigate the determinants of long-term growth. Our sample includes 21 small islands, giving legitimacy to the results for this group of countries. ${ }^{15}$

\section{B. The Proposed Econometric Approach}

The basic regression model is specified as follows:

$$
y_{i t}=\alpha+X_{i t} \beta+W_{i t} \delta+Z_{i} \lambda+\mu_{i}+\varepsilon_{i t}
$$

where $y_{i t}$ is the five-year average growth rate of country $i$ 's GDP per capita; $X_{i t}$ includes the logarithm of initial GDP per capita, government spending, school enrollment in primary education, trade openness, inflation, terms of trade growth, and life expectancy; $W_{i t}$ includes investment and tourism (tourist arrivals as percent of population, tourism receipts as percent of GDP, and receipts per tourist); and $Z_{i}$ includes time-invariant controls for country size such as size (squared kilometers of land area) and a dummy for small islands. ${ }^{16}$ The idea is that the variables in $X_{i t}$ and $Z_{i}$ are exogenous, while the ones in $W_{i t}$ may be correlated with the individual country effects and therefore need to be instrumented.

We resort to the use of the Hausman and Taylor (1981) instrumental variables approach. The choice is based on the following argument. The potential correlation of investment and tourism with the individual level effects leads to inconsistent estimators under the random effects approach, which was confirmed by a Hausman test. The alternative of fixed effects, while providing consistency, requires the elimination of the time-invariant controls. The Hausman and Taylor estimator allows us to control for the correlation of tourism and investment with the particular characteristics of each country, while keeping the timeinvariant covariates.

\footnotetext{
${ }^{15}$ The Appendix has a brief description of the data and sources, including a list of what we treat as small islands. Table 12 lists all the countries included in the sample.

${ }^{16}$ All explanatory variables enter the equation as the logarithm of 5-year averages, with the exception of size (land area in squared kilometers), the country-specific dummies, and the terms of trade growth measured as the percent growth rate (log difference) over the 5-year period.
} 


\section{The Impact of Tourism on Growth Levels}

The estimated results are consistent with the standard growth literature as shown in regression (1) in Table 7. Regressions (2) to (6) in the table explore different specifications, including different measures of tourism and size and their interactions. Nonetheless, the focus will be on arrivals per capita because it is the more robust measure. Inflation and government spending (in percent of GDP) detract from growth as expected, while openness, primary education, terms of trade, and life expectancy, have contributed positively to longterm economic growth in the sample. The results also suggest a conditional convergence across countries, as captured by a statistically significant negative coefficient on the logarithm of initial GDP per capita.

Most importantly, the augmented growth model indicates that tourism has been a significant factor in long-term economic growth. According to these results, a 10 percent increase in tourist arrivals per capita raises economic growth by about 0.2 percentage points. In addition, not only the volume of tourism but also the quality and value-added of it (proxied by receipts per tourist) are significant factors driving economic growth. This supports the strategy followed by some Caribbean countries of focusing on high-end tourism demand. ${ }^{17}$

The coefficient for country size is significant and always positive, implying that the small size of a country hinders its growth. Although it might seem that the coefficient is too small to matter, in the case of the Caribbean the size of their countries detracts around 0.3 percentage points from their growth each year, as shown below. In addition, being a small island has a negative impact on growth as shown in columns (3) to (6) of Table 7. This probably reflects the higher transportation costs, isolation from other markets, and lack of economies of scale that small islands have to deal with.

Interestingly, the positive contribution from specializing in tourism has helped to more than offset the negative impact of being a small island economy. As shown in Figure 4, tourist arrivals have added 4.1 percentage points to growth in the Caribbean region (given the higher than average tourist arrivals). ${ }^{18}$ On the other hand, the combination of the island geographical nature of the Caribbean and the small absolute size of their economies has lowered growth by 2.8 percentage points per year on average.

There also seems to exist scope for further growth by enhancing the role of the tourism sector, through both the number of arrivals and by how much each tourist spends. For instance, the estimated long-term growth would jump by 4 percentage points if tourist arrivals per capita in all the Caribbean countries were to match the level of tourist arrivals per

\footnotetext{
${ }^{17}$ We also control for the "exhaustion effect," approximated by a quadratic representation of the ratio of tourist arrivals to population. However, the positive and significant coefficient in estimation (6) of Table 7 suggests that the tourism industry has not yet reached a saturation point where the negative externalities of too many tourists (pollution, congestion, etc.) start to create negative effects on growth.

${ }^{18}$ To quantify the contribution of each factor to the economic growth of the Caribbean, we calculate the predicted growth rate of the model (column 5) in Table 7 using the average values of each explanatory variable for the Caribbean. We then calculate the contribution of each factor by replacing its value with the average value for the World. Figure 1 presents the results, where the green bars represent the variables that had a positive effect on growth, while the red bars indicate the variables with negative effects on long-term growth.
} 
capita in The Bahamas. ${ }^{19}$ Moreover, in terms of the average receipts per tourist, developing a niche and providing services that will attract high-end tourists could prove beneficial.

Figure 4. Caribbean: Factors Contributing to Caribbean Growth vis-à-vis the World

(In percent)

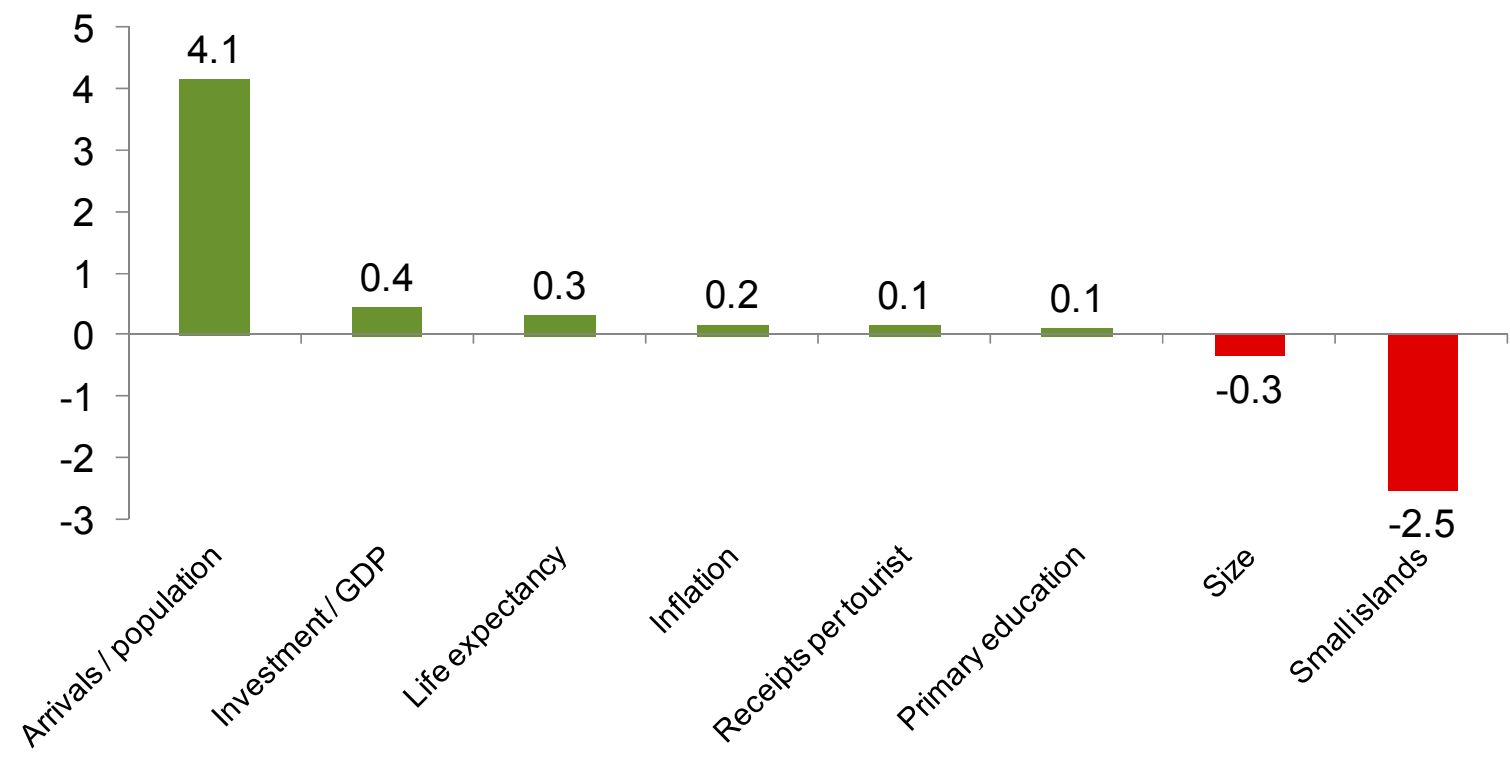

Source: Calculation s from regression (5) in Table 7.

Another important finding is that the Caribbean countries do not seem to benefit more from tourism than other countries in the world do. Table 8 shows the results of using interaction terms between the tourism arrivals per capita variable and dummy variables for both Caribbean countries and small islands. Although the results show a positive interaction between the dummy variables and tourism, the results are not statistically significant ${ }^{20}$ This would suggest that the tremendous contribution from tourism to growth in the Caribbean over the past 3 decades (Figure 4 ) is due to the relatively larger inflow of tourist per capita it receives compared to the rest of the world. Hence, the Caribbean countries would have to continue striving to attract large number of tourists if they want to keep tourism as an important engine of growth.

Finally, it is important to note that the results for tourism and small islands (including size) are robust to different estimation methodologies. To check for robustness of the tourism and size results, we estimated the same specification of column (5) in Table 7 using OLS, panel

\footnotetext{
${ }^{19}$ Achieving this would be no small feat, however. Over the past 30 years the Bahamas had on average 5.5 tourist arrivals per capita, while the rest of the Caribbean had an average of 0.6 tourist arrivals per capita over the same period.

${ }^{20}$ This contrasts with the results from Eugenio-Martín, Martín and Scarpa (2004) who find that low and middle income countries tend to benefit more from tourism than other countries.
} 
fixed effects (FE), panel random effects (RE), system GMM, and the Hausman-Taylor approach (see Table 9). The results show the robustness of tourism arrivals, small islands, and size, with the coefficients being statistically significant and displaying the correct sign. This is reassuring given the different results in the literature depending on the estimation methodology used.

\section{The Impact of Tourism on Growth Volatility}

While tourism is beneficial to the level of economic growth of small island economies, the impact of the current global crisis on demand for tourism in the Caribbean has brought to the fore the risks of a tourism-led growth strategy. The dependence on the demand for tourism from the source countries, it is argued, might increase the growth volatility by amplifying the impact of business cycles in those countries.

To test this hypothesis, we use the same specifications as in Table 7, but replace the dependent variable by the standard deviation of growth as shown in Table 10. The results show a positive correlation of growth volatility with inflation and government spending and a negative correlation with tourism. It appears that tourism not only raises per capita GDP growth but may also help to reduce its volatility. In particular, it seems that specializing in the supply of tourism services has an unambiguously positive effect for the countries that have adopted this strategy for their economic development. This is particularly so for smallisland economies, where the external demand for tourism helps to counter balance the effects of other factors that would otherwise increase volatility. ${ }^{21}$ In general one would expect that high levels of inflation would generate uncertainty in the economy and hence it would increase volatility. Since most emerging and developing countries have procyclical government spending, this variable amplifies the economic cycles and generates volatility.

It is important to note that size by itself does not appear to have an impact on volatility; however, being a small island does imply a higher level of output volatility for those economies. It is possible that the continuous exposure to external shocks, such as vulnerability to international food and fuel prices, and natural disasters (i.e., hurricanes, floods, etc.) is what generates volatility in the small island economies. ${ }^{22}$

Investment and trade openness contribute to raise both the level and the volatility of growth. A possible explanation for these results rests on the nature of the shocks to these variables: in the case of investment, sudden drops on the stock of human and physical capital have a long memory and may be hard to be offset within the 5-year period; in the case of openness, external vulnerabilities may be accentuated by the trade channels if a proper risk sharing

\footnotetext{
${ }^{21}$ Government spending, inflation and small islands have a clear absolute negative effect on growth, by lowering it and increasing its volatility.

${ }^{22}$ In the estimations, hurricanes seem to increase growth volatility. However, the results are sensitive to the specification used. When the number of hurricanes was included as an explanatory variable the estimation showed a positive and significant effect on volatility; however, when a dummy variable for countries that suffered hurricanes was included or when the estimated damages as percent of GDP were used the results turned out to be not significant. Since the results are not robust we do not present them, but they are available upon request.
} 
framework - either through trade diversification or through financial insurance/reserves - is not fully in place.

\section{E. Tourism, Size and Growth Accounting}

To explore the channels through which tourism and size affect growth, we regressed the growth rates of output per worker, capital per worker and TFP using the specification in column (5) of Table 7. The results presented in Table 11 show that tourism has a positive impact on both channels of growth, that is, it increases factor accumulation and productivity. However, the impact on capital accumulation is larger, which is explained by the important link of tourism and FDI, particularly in the Caribbean.

The volume of arrivals has a more pronounced effect on productivity than the one from high end tourism (given by receipts per tourist). Although both measures of tourism have a positive effect on productivity, the one from tourist arrivals is 5 times bigger than the one from receipts per tourist. ${ }^{23}$ This suggests that although high end tourism will bring some productivity improvements it is through the volume of arrivals that the Caribbean countries will find a much needed boost to productivity.

Interestingly, the size of a country while having a positive effect on capital accumulation does not affect productivity. On the other hand, being a small island affects (negatively) output growth through productivity but not through factor accumulation. This would imply that it is the island nature (not the size) of small islands that affects productivity. The lower productivity exhibited by small island countries is probably inherent to their nature. But it might be possible to tackle some of its negative effects by reducing transportation costs and improving connectedness within the region and with external markets.

\footnotetext{
${ }^{23}$ Additionally, the latter is only significant at the 10 percent level while the arrivals per capita variable is significant at the 1 percent level.
} 


\section{CONCLUding Remarks}

Although the Caribbean countries' per capita GDP increased significantly in the 1970s, in the last twenty years most of these countries have lost ground to the fast-growing emerging and developing countries. However, growth performance has been quite heterogeneous, with the ECCU countries recording the best performance overall but the commodity exporting countries in the region, such as Trinidad and Tobago, outpacing tourism-intensive countries in the last few years, helped by the boom in commodity prices. That said, some common factors can be identified.

First, the decline in TFP — despite high levels of capital accumulation - accounts for most of the deceleration faced by the region. Although it is difficult to pinpoint the factors behind the large decline in TFP, as it could represent anything from lack of complementary factors and innovation to simple measurement errors. Efforts to improve TFP through stronger institutions, and adoption of new technologies that are labor-augmenting, are bound to help boost growth in the region.

The TFP decline is partially a result of the transition from a labor intensive agricultural sector to a more capital intensive tourism sector. Given that the labor data does not allow us to control for the effect of unemployment in the labor input, this effect is captured by the TFP component. Hence, it is possible that the decline in TFP is partially explained by our measure of the labor input in the growth accounting exercise. However, it must be emphasized that over a sufficiently long period of time there is not a systematic bias in the average TFP growth, since the overestimation of TFP in periods of higher unemployment will cancel out with its underestimation in periods of lower unemployment.

Second, the study shows that tourism has been a major contributor to long-term economic growth and there is significant scope in many countries to boost growth by enhancing the performance of this sector. A 10 percent increase in tourist arrivals per capita increases economic growth by about 0.2 percentage points. We also find that tourism not only raises per capita GDP growth but may also help to reduce its volatility. Furthermore, both tourist arrivals and high-end tourism have a positive effect on productivity, with the former having a bigger impact. This suggests that the tourism sector can still be an engine of growth in the future of the region. In this regard, anecdotal evidence suggests that enhancing product quality in the tourism sector either through improvements in existing products or developing new products like ecotourism could yield significant dividends. Lowering costs could also help improve the competitiveness of the region, but this is outside the scope of this paper and deserves to be explored in future research.

Third, the small size and the island nature of these economies appear to have adversely affected growth through their impact on productivity and capital accumulation. We estimate that the cost of these two factors over the past 30 years has been a lower annual GDP growth rate of 2.8 percentage points per year, on average. Regional integration that helps to exploit economies of scale and underplay the difficult access and higher transport costs to bigger markets could have beneficial effects. While policymakers recognize this and efforts are ongoing, progress in this area has been rather slow. Further research in this area that quantifies some of the benefits could perhaps help to accelerate this process. 


\section{REFERENCES}

Alesina, Alberto; Enrico Spolaore; and Romain Wacziarg, 2005, "Trade, Growth and the Size of Countries." In Handbook of Economic Growth, Vol. 1B, edited by Philippe Aghion and Steven N. Durlauf. (Elsiever).

Arellano, Manuel, and Stephen Bond, 1991, "Some tests of specification for panel data: Monte Carlo evidence and an application to employment equations," Review of Economic Studies, Vol. 58, pp. 277-97.

Arezki, Rabah, Reda Cherif, and John Piotrowski, 2009, “Tourism Specialization and Economic Development: Evidence from the UNESCO World Heritage List," IMF Working Paper 09/176 (Washington: International Monetary Fund).

Barro, Robert, 1998, "Notes on Growth Accounting,” NBER Working Paper 6654 (Cambridge, MA: National Bureau of Economic Research). , and Jong-Wha Lee, 1994, "Sources of Economic Growth," Carnegie-Rochester Conference Series on Public Policy, Vol. 40, pp. 1-46.

Blundell, Richard, and Stephen Bond, 1998, "Initial conditions and moment restrictions in dynamic panel data models," Journal of Econometrics, Vol. 87, pp. 115-43.

Cashin, Paul, 2006, "Key Features of Caribbean Business Cycles" in Caribbean: From Vulnerability to Sustained Growth, ed. by Ratna Sahay, David Robinson and Paul Cashin (Washington: International Monetary Fund).

EM-DAT: The OFDA/CRED International Disaster Database -www.emdat.be-Université Catholique de Louvain - Brussels - Belgium.

Denison, Edward, 1962, "Sources of Growth in the United States and the Alternative Before Us," Supplement Paper 13 (New York: Committee for Economic Development). , Zvi Griliches and Dale Jorgenson, 1972, "The Measurement of Productivity" Survey of Current Business 52 (May, part 2) Pages 3-111 (special issue).

Eugenio-Martín, Juan, Noelia Martín and Riccardo Scarpa, 2004, “Tourism and Economic Growth in Latin American Countries: A Panel Data Approach,” Nota di Lavoro 26.2004 (Milan: Fondazione Eni Enrico Mattei).

Hall, Robert and Charles Jones, 1999, "Why do Some Countries Produce so Much More Output per Worker than Others?," Quarterly Journal of Economics, Vol. 114, pp. 83-116.

Hausman, Jerry, and William Taylor, 1981, "Panel data and unobservable individual effects," Econometrica, Vol. 49, pp. 1377-398.

Heston, Alan; Robert Summers and Bettina Aten, 2009, "Penn World Table v. 6.3," Center for International Comparisons of Production, Income and Prices, (Philadelphia: University of Pennsylvania). 
IMF, 2011, "World Economic Outlook: Slow Growth, Rising Risk," September 2011 WEO (Washington: International Monetary Fund).

Jorgenson, Dale and Zvi Griliches, 1967, "The Explanation of Productivity Change," Review of Economic Studies, Vol. 34, pp. 249-80.

Lee, Jong-Wha, 2005, "Human capital and productivity for Korea's sustained economic growth," Journal of Asian Economics, Vol. 16, pp. 663-87.

Loayza, Norman, Pablo Fajnzylber and Cesar Calderon, 2004, Economic Growth in Latin America and the Caribbean: Stylized Facts, Explanations, and Forecasts (Washington: World Bank).

Mlachila, Montfort, Paul Cashin and Cleary Haines, 2010, "Caribbean Bananas: The Macroeconomic Impact of Trade Preference Erosion,” IMF Working Paper 10/59 (Washington: International Monetary Fund).

Sequeira, Tiago and Carla Campos, 2007, "International Tourism and Economic Growth: A Panel Data Approach," in Advances in Modern Tourism Research: Economic Perspectives, ed. by Álvaro Matias, Peter Nijkamp and Paulo Neto (New York: Physica-Verlag). , and Paulo Nunes, 2008, "Does Tourism Influence Economic Growth? A Dynamic Panel Data Approach," Applied Economics, Vol. 40, pp. 2431-2441.

Solow, Robert, 1957, "Technical Change and the Aggregate Production Function," Review of Economics and Statistics, Vol. 39, pp. 312-320.

Sosa, Sebastian and Paul Cashin, 2009, "Macroeconomic Fluctuations in the Caribbean: the Role of Climatic and External Shocks," IMF Working Paper 09/159 (Washington: International Monetary Fund).

Thacker, Nita and Sebastian Acevedo, 2010, "A Cross-Country Perspective on Growth in the Caribbean: The Role of Tourism and Debt," in: Regional Economic Outlook: Western Hemisphere: Heating up in the south, cooler in the north, (Washington: International Monetary Fund).

World Tourism Organization, 1980-2009, Yearbook of Tourism Statistics (Madrid: World Tourism Organization). 


\section{APPENDIX}

\section{Data and Variables}

- $\quad$ Average real per capita GDP in 5 years intervals: 1979-1983, 1984-1988, 19891993, 1994-1998, 1999-2003 and 2004-2007 (4 year average for the last period). (Source: PWT 6.3).

- $\quad$ Convergence: Real per capita GDP at the beginning of each 5 year interval: 1979, 1984, 1989, 1994, 1999 and 2004. (Source: PWT 6.3).

- $\quad$ Government spending / GDP: Government spending as a percentage of GDP. (Source: PWT 6.3).

- $\quad$ Primary education: School enrollment primary (\% gross). Gross enrollment ratio is the ratio of total enrollment, regardless of age, to the population of the age group that officially corresponds to the level of education shown. (Source: World Development Indicators, WB).

- $\quad$ Openness: Exports plus Imports as a percentage of GDP. (Source: PWT 6.3).

- Inflation: CPI percentage change, $\log (1+$ Inflation). (Source: International Financial Statistics, IMF).

- $\quad$ Terms of trade: Growth rate (in percent) of the Terms of trade of goods and services. (Source: World Economic Outlook, IMF).

- $\quad$ Life expectancy: Life expectancy at birth, total (years). (Source: World Development Indicators, WB).

- $\quad$ Size: Land area in millions of square kilometers. (Source: World Development Indicators, WB).

- Investment / GDP: Investment as a percentage of GDP. (Source: PWT 6.3).

- $\quad$ Arrivals / population: Stay-over tourist arrivals over total population. (Source: Yearbook of Tourism Statistics, WTO; and PWT 6.3).

- $\quad$ Small islands: Antigua \& Barbuda, Bahamas, Barbados, Bermuda, Cape Verde, Comoros, Cuba, Cyprus, Dominica, Dominican Republic, Fiji, Grenada, Haiti, Jamaica, Kiribati, Maldives, Malta, Marshall Islands, Mauritius, Federated States of Micronesia, Palau, Papua New Guinea, Samoa, Sao Tome \& Principe, Seychelles, Solomon Islands, St. Kitts \& Nevis, St. Lucia, St. Vincent \& the Grenadines, Tonga, Trinidad \& Tobago and Vanuatu.

- $\quad$ Receipts per tourist: Total tourism receipts divided by tourist stay-over arrivals. It covers all goods and services acquired for personal use by travelers during their visits, except international carriage of passengers. (Source: International Financial Statistics, IMF; complemented in some years with the information from the Yearbook of Tourism Statistics, WTO). 
Table 1. ECCU: Growth Accounting 1970-2007

(In percent, adjusted for the effects of hurricanes on capital)

\begin{tabular}{|c|c|c|c|c|c|c|c|}
\hline & \multicolumn{4}{|c|}{ Average annual growth } & \multicolumn{3}{|c|}{$\begin{array}{l}\text { Contribution to growth } \\
\text { (\% point) }\end{array}$} \\
\hline & Output & Capital & Labor & TFP & $\mathbf{K}$ & $\mathbf{L}$ & TFP \\
\hline $\begin{array}{l}\text { Antigua and Barbuda /1 } \\
1971-1980\end{array}$ & 4.52 & 6.95 & 1.84 & 0.89 & 2.43 & 1.20 & 0.89 \\
\hline $1981-1990$ & & & & & & & \\
\hline $1991-2000$ & 3.73 & 4.90 & 1.89 & 0.79 & 1.72 & 1.23 & 0.79 \\
\hline 2001-2007 & 4.97 & 8.13 & 1.81 & 0.95 & 2.84 & 1.18 & 0.95 \\
\hline Dominica /2 & 2.55 & 3.32 & 0.74 & 0.91 & 1.16 & 0.48 & 0.91 \\
\hline 1971-1980 & 2.93 & -15.73 & -0.20 & 8.56 & -5.50 & -0.13 & 8.56 \\
\hline $1981-1990$ & 5.22 & 9.97 & 0.38 & 1.48 & 3.49 & 0.25 & 1.48 \\
\hline $1991-2000$ & 1.58 & 2.23 & 1.09 & 0.09 & 0.78 & 0.71 & 0.09 \\
\hline $2001-2007$ & -0.05 & 3.54 & 1.14 & -2.03 & 1.24 & 0.74 & -2.03 \\
\hline Grenada & 4.13 & 5.47 & 0.78 & 1.71 & 1.92 & 0.51 & 1.71 \\
\hline 1971-1980 & 3.98 & 4.56 & 1.19 & 1.61 & 1.59 & 0.77 & 1.61 \\
\hline $1981-1990$ & 7.39 & 8.28 & 0.43 & 4.21 & 2.90 & 0.28 & 4.21 \\
\hline $1991-2000$ & 3.70 & 5.65 & 0.37 & 1.48 & 1.98 & 0.24 & 1.48 \\
\hline $2001-2007$ & 0.32 & 2.50 & 1.28 & -1.39 & 0.88 & 0.83 & -1.39 \\
\hline St. Kitts \& Nevis /2 & 4.88 & 5.14 & -0.18 & 3.20 & 1.80 & -0.12 & 3.20 \\
\hline $1971-1980$ & 7.61 & 5.21 & -0.41 & 6.05 & 1.82 & -0.26 & 6.05 \\
\hline $1981-1990$ & 5.43 & 5.60 & -0.65 & 3.90 & 1.96 & -0.42 & 3.90 \\
\hline $1991-2000$ & 3.22 & -0.05 & -0.33 & 3.45 & -0.02 & -0.21 & 3.45 \\
\hline 2001-2007 & 5.28 & 11.86 & 0.78 & 0.62 & 4.15 & 0.50 & 0.62 \\
\hline St. Lucia 3/ & 3.99 & 6.12 & 2.28 & 0.37 & 2.14 & 1.48 & 0.37 \\
\hline 1971-1980 & 5.40 & 2.44 & 2.96 & 2.62 & 0.85 & 1.92 & 2.62 \\
\hline $1981-1990$ & 4.85 & 9.93 & 2.36 & -0.16 & 3.47 & 1.53 & -0.16 \\
\hline $1991-2000$ & 2.62 & 7.87 & 2.00 & -1.44 & 2.75 & 1.30 & -1.44 \\
\hline 2001-2007 & 2.72 & 3.46 & 1.60 & 0.47 & 1.21 & 1.04 & 0.47 \\
\hline $\begin{array}{l}\text { St. Vincent \& the } \\
\text { Grenadines }\end{array}$ & 4.15 & 4.09 & 1.43 & 1.79 & 1.43 & 0.93 & 1.79 \\
\hline 1971-1980 & 2.99 & 1.76 & 2.28 & 0.89 & 0.62 & 1.48 & 0.89 \\
\hline $1981-1990$ & 6.85 & 5.36 & 1.82 & 3.80 & 1.88 & 1.18 & 3.80 \\
\hline $1991-2000$ & 2.22 & 4.98 & 0.77 & -0.02 & 1.74 & 0.50 & -0.02 \\
\hline $2001-2007$ & 4.73 & 4.36 & 0.63 & 2.79 & 1.53 & 0.41 & 2.79 \\
\hline Average & 3.99 & 5.00 & 1.12 & 1.52 & 1.75 & 0.73 & 1.52 \\
\hline
\end{tabular}

Source: Emergency Disaster Database (EM-DAT), CRED (2010); Heston, Summers, and Aten (2009); and IMF staff calculations. 1/ Data available only since 1996.

2/ Data available only since 1977.

3/ The data for St. Lucia omits EM-DAT's entry of US\$1 billion damages in 1988, which is erroneous. 
Table 2. Other Caribbean: Growth Accounting 1970-2007

(In percent, adjusted for the effects of hurricanes on capital)

\begin{tabular}{|c|c|c|c|c|c|c|c|}
\hline & \multicolumn{4}{|c|}{ Average annual growth } & \multicolumn{3}{|c|}{$\begin{array}{c}\text { Contribution to growth } \\
\text { (\% point) }\end{array}$} \\
\hline & Output & Capital & Labor & TFP & $\mathrm{K}$ & $\mathbf{L}$ & TFP \\
\hline Bahamas & 2.34 & 5.02 & 2.30 & -0.91 & 1.76 & 1.49 & -0.91 \\
\hline 1971-1980 & 2.59 & 1.46 & 2.98 & 0.14 & 0.51 & 1.94 & 0.14 \\
\hline $1981-1990$ & 3.22 & 7.21 & 2.95 & -1.22 & 2.52 & 1.92 & -1.22 \\
\hline $1991-2000$ & 2.12 & 5.80 & 1.64 & -0.98 & 2.03 & 1.06 & -0.98 \\
\hline 2001-2007 & 1.06 & 5.87 & 1.35 & -1.87 & 2.06 & 0.88 & -1.87 \\
\hline Barbados & 1.97 & 1.74 & 1.15 & 0.61 & 0.61 & 0.75 & 0.61 \\
\hline 1971-1980 & 4.41 & 3.58 & 1.68 & 2.07 & 1.25 & 1.09 & 2.07 \\
\hline $1981-1990$ & 0.54 & 1.57 & 1.17 & -0.77 & 0.55 & 0.76 & -0.77 \\
\hline $1991-2000$ & 1.05 & 0.37 & 0.84 & 0.37 & 0.13 & 0.55 & 0.37 \\
\hline $2001-2007$ & 1.83 & 1.28 & 0.83 & 0.84 & 0.45 & 0.54 & 0.84 \\
\hline Belize & 4.46 & 3.23 & 2.89 & 1.45 & 1.13 & 1.88 & 1.45 \\
\hline 1971-1980 & 4.05 & 4.12 & 1.84 & 1.41 & 1.44 & 1.19 & 1.41 \\
\hline $1981-1990$ & 4.06 & 1.76 & 3.16 & 1.39 & 0.62 & 2.06 & 1.39 \\
\hline $1991-2000$ & 4.91 & 3.05 & 3.35 & 1.67 & 1.07 & 2.18 & 1.67 \\
\hline 2001-2007 & 4.97 & 4.33 & 3.33 & 1.29 & 1.52 & 2.17 & 1.29 \\
\hline Guyana & 0.49 & 0.78 & 1.05 & -0.46 & 0.27 & 0.68 & -0.46 \\
\hline 1971-1980 & 2.03 & 3.38 & 1.77 & -0.30 & 1.18 & 1.15 & -0.30 \\
\hline $1981-1990$ & -5.36 & -1.17 & 0.60 & -5.34 & -0.41 & 0.39 & -5.34 \\
\hline $1991-2000$ & 5.03 & 1.06 & 1.02 & 4.00 & 0.37 & 0.66 & 4.00 \\
\hline 2001-2007 & 0.17 & -0.56 & 0.69 & -0.09 & -0.20 & 0.45 & -0.09 \\
\hline Jamaica & 1.09 & 0.81 & 1.73 & -0.31 & 0.28 & 1.12 & -0.31 \\
\hline 1971-1980 & -0.99 & -0.25 & 2.60 & -2.60 & -0.09 & 1.69 & -2.60 \\
\hline $1981-1990$ & 2.60 & -0.89 & 1.34 & 2.05 & -0.31 & 0.87 & 2.05 \\
\hline $1991-2000$ & 1.37 & 2.73 & 1.41 & -0.50 & 0.96 & 0.91 & -0.50 \\
\hline $2001-2007$ & 1.52 & 2.00 & 1.48 & -0.14 & 0.70 & 0.96 & -0.14 \\
\hline Suriname & 1.53 & 3.51 & 1.49 & -0.67 & 1.23 & 0.97 & -0.67 \\
\hline 1971-1980 & 1.50 & 3.31 & 0.77 & -0.16 & 1.16 & 0.50 & -0.16 \\
\hline $1981-1990$ & 1.10 & 0.06 & 2.05 & -0.26 & 0.02 & 1.33 & -0.26 \\
\hline $1991-2000$ & -0.71 & 3.20 & 1.47 & -2.78 & 1.12 & 0.95 & -2.78 \\
\hline 2001-2007 & 5.39 & 9.17 & 1.73 & 1.06 & 3.21 & 1.12 & 1.06 \\
\hline Trinidad \& Tobago & 3.28 & 2.03 & 1.51 & 1.59 & 0.71 & 0.98 & 1.59 \\
\hline $1971-1980$ & 4.54 & 4.01 & 2.59 & 1.45 & 1.40 & 1.68 & 1.45 \\
\hline $1981-1990$ & -2.33 & 2.47 & 1.38 & -4.09 & 0.87 & 0.89 & -4.09 \\
\hline $1991-2000$ & 4.83 & -0.24 & 1.12 & 4.19 & -0.09 & 0.73 & 4.19 \\
\hline 2001-2007 & 7.28 & 1.82 & 0.70 & 6.19 & 0.64 & 0.45 & 6.19 \\
\hline Grand Total & 2.17 & 2.45 & 1.73 & 0.19 & 0.86 & 1.12 & 0.19 \\
\hline
\end{tabular}

Source: Emergency Disaster Database (EM-DAT), CRED (2010); Heston, Summers, and Aten (2009); and IMF staff calculations. 
Table 3. ECCU: Output Growth and its Components:

Ratio to Barbados Values, 1970-2007

(In percent, adjusted for the effects of hurricanes on capital)

\begin{tabular}{|c|c|c|c|c|c|}
\hline Country & Year & $\begin{array}{c}\text { Output } \\
\text { per worker, } \\
y\end{array}$ & $\begin{array}{c}\text { Capital } \\
\text { per worker, } \\
k\end{array}$ & $\begin{array}{c}\text { Factors of } \\
\text { production, } \\
k^{\alpha}\end{array}$ & $\begin{array}{c}\text { Productivity, } \\
\text { A }\end{array}$ \\
\hline Antigua and Barbuda & $\begin{array}{l}1970 \\
1980 \\
1990 \\
2000 \\
2007\end{array}$ & $\begin{array}{l}0.70 \\
0.80\end{array}$ & $\begin{array}{l}0.34 \\
0.52\end{array}$ & $\begin{array}{l}0.69 \\
0.79\end{array}$ & $\begin{array}{l}1.01 \\
1.01\end{array}$ \\
\hline Dominica & $\begin{array}{l}1970 \\
1980 \\
1990 \\
2000 \\
2007\end{array}$ & $\begin{array}{l}0.14 \\
0.24 \\
0.24 \\
0.21\end{array}$ & $\begin{array}{l}0.06 \\
0.14 \\
0.17 \\
0.19\end{array}$ & $\begin{array}{l}0.37 \\
0.50 \\
0.53 \\
0.56\end{array}$ & $\begin{array}{l}0.37 \\
0.47 \\
0.46 \\
0.37\end{array}$ \\
\hline Grenada & $\begin{array}{l}1970 \\
1980 \\
1990 \\
2000 \\
2007\end{array}$ & $\begin{array}{l}0.26 \\
0.27 \\
0.57 \\
0.77 \\
0.68\end{array}$ & $\begin{array}{l}0.25 \\
0.29 \\
0.62 \\
1.10 \\
1.17\end{array}$ & $\begin{array}{l}0.62 \\
0.65 \\
0.85 \\
1.04 \\
1.05\end{array}$ & $\begin{array}{l}0.43 \\
0.41 \\
0.68 \\
0.75 \\
0.64\end{array}$ \\
\hline St. Kitts \& Nevis & $\begin{array}{l}1970 \\
1980 \\
1990 \\
2000 \\
2007\end{array}$ & $\begin{array}{l}0.19 \\
0.36 \\
0.50 \\
0.64\end{array}$ & $\begin{array}{l}0.15 \\
0.28 \\
0.30 \\
0.63\end{array}$ & $\begin{array}{l}0.52 \\
0.64 \\
0.66 \\
0.85\end{array}$ & $\begin{array}{l}0.36 \\
0.57 \\
0.77 \\
0.75\end{array}$ \\
\hline St. Lucia $1 /$ & $\begin{array}{l}1970 \\
1980 \\
1990 \\
2000 \\
2007\end{array}$ & $\begin{array}{l}0.39 \\
0.38 \\
0.52 \\
0.53 \\
0.54\end{array}$ & $\begin{array}{l}0.14 \\
0.11 \\
0.22 \\
0.41 \\
0.46\end{array}$ & $\begin{array}{l}0.50 \\
0.46 \\
0.59 \\
0.73 \\
0.76\end{array}$ & $\begin{array}{l}0.78 \\
0.82 \\
0.88 \\
0.73 \\
0.71\end{array}$ \\
\hline $\begin{array}{l}\text { St. Vincent \& the } \\
\text { Grenadines }\end{array}$ & $\begin{array}{l}1970 \\
1980 \\
1990 \\
2000 \\
2007 \\
\end{array}$ & $\begin{array}{l}0.14 \\
0.11 \\
0.19 \\
0.22 \\
0.27 \\
\end{array}$ & $\begin{array}{l}0.11 \\
0.09 \\
0.12 \\
0.19 \\
0.24 \\
\end{array}$ & $\begin{array}{l}0.46 \\
0.42 \\
0.47 \\
0.56 \\
0.60 \\
\end{array}$ & $\begin{array}{l}0.29 \\
0.26 \\
0.41 \\
0.39 \\
0.45 \\
\end{array}$ \\
\hline
\end{tabular}

Source: Emergency Disaster Database (EM-DAT), CRED (2010); Heston, Summers, and Aten (2009); and IMF staff calculations.

$1 /$ The data for St. Lucia omits EM-DAT's entry of US\$1 billion damages in 1988, which is erroneous. 
Table 4. Other Caribbean: Output Growth and its Components:

Ratio to Barbados Values, 1970-2007

(In percent, adjusted for the effects of hurricanes on capital)

\begin{tabular}{|c|c|c|c|c|c|}
\hline Country & Year & $\begin{array}{c}\text { Output } \\
\text { per worker, } \\
y\end{array}$ & $\begin{array}{c}\text { Capital } \\
\text { per worker, } \\
k\end{array}$ & $\begin{array}{c}\text { Factors of } \\
\text { production, } \\
k^{\alpha}\end{array}$ & $\begin{array}{c}\text { Productivity, } \\
\boldsymbol{A}\end{array}$ \\
\hline \multirow[t]{5}{*}{ Bahamas } & 1970 & 1.47 & 0.54 & 0.81 & 1.82 \\
\hline & 1980 & 1.07 & 0.38 & 0.72 & 1.50 \\
\hline & 1990 & 1.17 & 0.56 & 0.82 & 1.43 \\
\hline & 2000 & 1.19 & 0.90 & 0.96 & 1.23 \\
\hline & 2007 & 1.09 & 1.19 & 1.06 & 1.02 \\
\hline \multirow[t]{5}{*}{ Belize } & 1970 & 0.37 & 0.35 & 0.69 & 0.54 \\
\hline & 1980 & 0.35 & 0.37 & 0.70 & 0.50 \\
\hline & 1990 & 0.41 & 0.30 & 0.66 & 0.63 \\
\hline & 2000 & 0.47 & 0.31 & 0.66 & 0.70 \\
\hline & 2007 & 0.49 & 0.32 & 0.67 & 0.73 \\
\hline \multirow[t]{5}{*}{ Guyana } & 1970 & 0.18 & 0.29 & 0.65 & 0.27 \\
\hline & 1980 & 0.14 & 0.29 & 0.64 & 0.21 \\
\hline & 1990 & 0.08 & 0.23 & 0.60 & 0.13 \\
\hline & 2000 & 0.12 & 0.24 & 0.61 & 0.19 \\
\hline & 2007 & 0.10 & 0.21 & 0.58 & 0.18 \\
\hline \multirow[t]{5}{*}{ Jamaica } & 1970 & 0.66 & 0.79 & 0.92 & 0.71 \\
\hline & 1980 & 0.35 & 0.49 & 0.78 & 0.45 \\
\hline & 1990 & 0.43 & 0.38 & 0.71 & 0.60 \\
\hline & 2000 & 0.41 & 0.45 & 0.76 & 0.55 \\
\hline & 2007 & 0.38 & 0.45 & 0.76 & 0.51 \\
\hline \multirow[t]{5}{*}{ Suriname } & 1970 & 0.62 & 0.39 & 0.72 & 0.86 \\
\hline & 1980 & 0.50 & 0.42 & 0.74 & 0.68 \\
\hline & 1990 & 0.49 & 0.33 & 0.68 & 0.72 \\
\hline & 2000 & 0.37 & 0.41 & 0.73 & 0.50 \\
\hline & 2007 & 0.44 & 0.67 & 0.87 & 0.50 \\
\hline \multirow[t]{5}{*}{ Trinidad \& Tobago } & 1970 & 0.73 & 0.63 & 0.85 & 0.86 \\
\hline & 1980 & 0.67 & 0.60 & 0.84 & 0.80 \\
\hline & 1990 & 0.49 & 0.64 & 0.86 & 0.57 \\
\hline & 2000 & 0.69 & 0.59 & 0.83 & 0.83 \\
\hline & 2007 & 1.02 & 0.61 & 0.84 & 1.21 \\
\hline
\end{tabular}

Source: Emergency Disaster Database (EM-DAT), CRED (2010); Heston, Summers, and Aten (2009); and IMF staff calculations. 
Table 5. ECCU: Output Growth and its Components:

Ratio to U.S. Values, 1970-2007

(In percent, adjusted for the effects of hurricanes on capital)

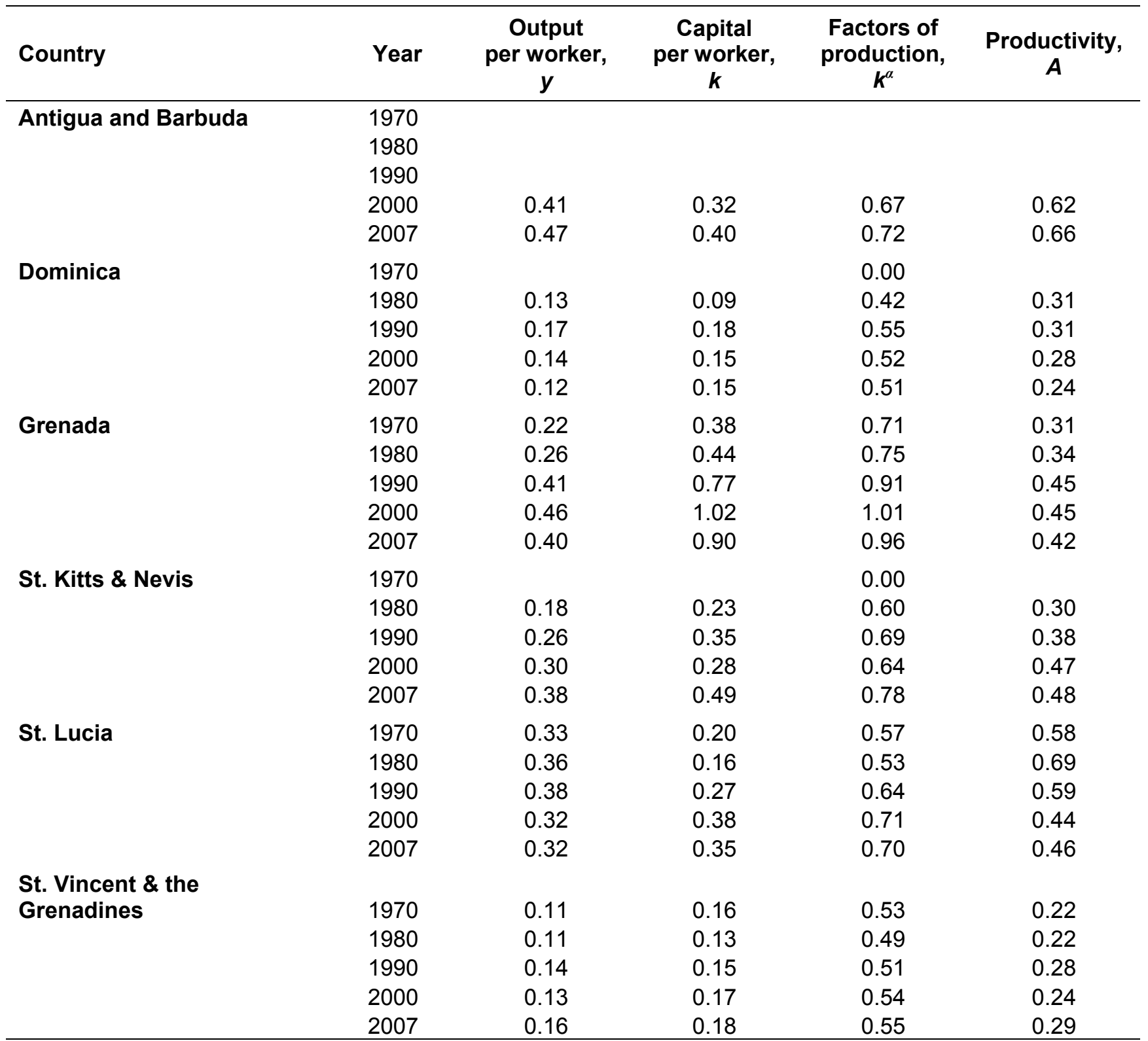

Source: Emergency Disaster Database (EM-DAT), CRED (2010); Heston, Summers, and Aten (2009); and IMF staff calculations. Note: The data for St. Lucia omits EM-DAT's entry of US\$1 billion damages in 1988, which is erroneous. 
Table 6. Other Caribbean: Output Growth and its Components:

Ratio to U.S. Values, 1970-2007

(In percent, adjusted for the effects of hurricanes on capital)

\begin{tabular}{|c|c|c|c|c|c|}
\hline Country & Year & $\begin{array}{c}\text { Output } \\
\text { per worker, } \\
y\end{array}$ & $\begin{array}{c}\text { Capital } \\
\text { per worker, } \\
\boldsymbol{k}\end{array}$ & $\begin{array}{c}\text { Factors of } \\
\text { production, } \\
\boldsymbol{k}^{\alpha}\end{array}$ & $\begin{array}{c}\text { Productivity, } \\
\text { A }\end{array}$ \\
\hline \multirow[t]{5}{*}{ The Bahamas } & 1970 & 1.24 & 0.80 & 0.92 & 1.34 \\
\hline & 1980 & 1.03 & 0.58 & 0.82 & 1.25 \\
\hline & 1990 & 0.85 & 0.70 & 0.88 & 0.96 \\
\hline & 2000 & 0.70 & 0.83 & 0.94 & 0.75 \\
\hline & 2007 & 0.64 & 0.92 & 0.97 & 0.66 \\
\hline \multirow[t]{5}{*}{ Barbados } & 1970 & 0.84 & 1.48 & 1.15 & 0.74 \\
\hline & 1980 & 0.96 & 1.50 & 1.15 & 0.84 \\
\hline & 1990 & 0.73 & 1.25 & 1.08 & 0.67 \\
\hline & 2000 & 0.59 & 0.92 & 0.97 & 0.61 \\
\hline & 2007 & 0.59 & 0.77 & 0.91 & 0.65 \\
\hline \multirow[t]{5}{*}{ Belize } & 1970 & 0.32 & 0.52 & 0.80 & 0.40 \\
\hline & 1980 & 0.34 & 0.55 & 0.81 & 0.42 \\
\hline & 1990 & 0.30 & 0.38 & 0.71 & 0.42 \\
\hline & 2000 & 0.28 & 0.29 & 0.65 & 0.43 \\
\hline & 2007 & 0.29 & 0.25 & 0.62 & 0.47 \\
\hline \multirow[t]{5}{*}{ Guyana } & 1970 & 0.15 & 0.43 & 0.75 & 0.20 \\
\hline & 1980 & 0.13 & 0.43 & 0.74 & 0.18 \\
\hline & 1990 & 0.06 & 0.29 & 0.65 & 0.09 \\
\hline & 2000 & 0.07 & 0.22 & 0.59 & 0.12 \\
\hline & 2007 & 0.06 & 0.17 & 0.53 & 0.12 \\
\hline \multirow[t]{5}{*}{ Jamaica } & 1970 & 0.55 & 1.16 & 1.05 & 0.53 \\
\hline & 1980 & 0.34 & 0.73 & 0.90 & 0.38 \\
\hline & 1990 & 0.31 & 0.47 & 0.77 & 0.40 \\
\hline & 2000 & 0.24 & 0.41 & 0.73 & 0.33 \\
\hline & 2007 & 0.23 & 0.35 & 0.69 & 0.33 \\
\hline \multirow[t]{5}{*}{ Suriname } & 1970 & 0.52 & 0.58 & 0.83 & 0.63 \\
\hline & 1980 & 0.49 & 0.63 & 0.85 & 0.57 \\
\hline & 1990 & 0.35 & 0.41 & 0.73 & 0.48 \\
\hline & 2000 & 0.22 & 0.38 & 0.71 & 0.30 \\
\hline & 2007 & 0.26 & 0.52 & 0.79 & 0.33 \\
\hline \multirow[t]{5}{*}{ Trinidad \& Tobago } & 1970 & 0.61 & 0.93 & 0.97 & 0.63 \\
\hline & 1980 & 0.64 & 0.90 & 0.96 & 0.67 \\
\hline & 1990 & 0.36 & 0.80 & 0.92 & 0.39 \\
\hline & 2000 & 0.41 & 0.54 & 0.81 & 0.51 \\
\hline & 2007 & 0.60 & 0.48 & 0.77 & 0.78 \\
\hline
\end{tabular}

Source: Emergency Disaster Database (EM-DAT), CRED (2010); Heston, Summers, and Aten (2009); and IMF staff calculations. 
Table 7. Tourism and Growth Estimations

\begin{tabular}{|c|c|c|c|c|c|c|}
\hline \multirow{2}{*}{ Variables } & \multicolumn{6}{|c|}{ GDP Growth } \\
\hline & (1) & (2) & $(3)$ & $(4)$ & (5) & (6) \\
\hline \multirow[t]{2}{*}{ Convergence } & $-1.879^{\star * \star}$ & $-3.348^{* * *}$ & $-3.457^{* * *}$ & $-1.704^{* * *}$ & $-3.801^{\star \star \star}$ & $-3.683^{* * *}$ \\
\hline & $(0.319)$ & $(0.404)$ & $(0.403)$ & $(0.328)$ & $(0.421)$ & $(0.416)$ \\
\hline \multirow[t]{2}{*}{ Government spending / GDP } & $-0.874^{* *}$ & $-0.825^{*}$ & -0.660 & $-0.992^{* *}$ & -0.419 & -0.592 \\
\hline & $(0.440)$ & $(0.464)$ & $(0.455)$ & $(0.447)$ & $(0.472)$ & $(0.462)$ \\
\hline \multirow[t]{2}{*}{ Primary education } & $1.966^{\star * *}$ & $1.217^{*}$ & 1.131 & $1.859^{* *}$ & 0.780 & $1.521^{\star \star}$ \\
\hline & $(0.710)$ & $(0.730)$ & $(0.722)$ & $(0.739)$ & $(0.751)$ & $(0.746)$ \\
\hline \multirow[t]{2}{*}{ Openness } & $1.339^{\star * *}$ & 0.200 & 0.279 & $1.096^{* * *}$ & 0.036 & 0.140 \\
\hline & $(0.354)$ & $(0.397)$ & $(0.387)$ & $(0.373)$ & $(0.403)$ & $(0.397)$ \\
\hline \multirow[t]{2}{*}{ Inflation } & $-2.807^{\star \star *}$ & $-2.682^{\star \star *}$ & $-2.627^{* \star \star}$ & $-3.035^{\star \star \star}$ & $-2.581^{* * *}$ & $-2.665^{\star \star *}$ \\
\hline & $(0.509)$ & $(0.482)$ & $(0.480)$ & $(0.513)$ & $(0.491)$ & $(0.481)$ \\
\hline \multirow[t]{2}{*}{ Terms of trade } & $0.036^{*}$ & $0.075^{\star \star *}$ & $0.074^{\star * *}$ & $0.040^{* *}$ & $0.083^{* * \star}$ & $0.076^{\star * \star}$ \\
\hline & $(0.020)$ & $(0.019)$ & $(0.019)$ & $(0.020)$ & $(0.019)$ & $(0.019)$ \\
\hline \multirow[t]{2}{*}{ Life expectancy } & $7.398^{\star * \star}$ & $5.826^{\star * *}$ & $5.677^{\star *}$ & $5.746^{\star *}$ & $4.417^{\star \star}$ & $6.101^{* * *}$ \\
\hline & $(2.324)$ & $(2.224)$ & $(2.218)$ & $(2.283)$ & $(2.200)$ & $(2.229)$ \\
\hline \multirow[t]{2}{*}{ Investment / GDP } & $2.594^{* \star *}$ & $1.016^{* *}$ & $1.108^{* *}$ & $1.795^{\star * *}$ & 0.728 & $1.177^{\star * *}$ \\
\hline & $(0.467)$ & $(0.451)$ & $(0.452)$ & $(0.480)$ & $(0.446)$ & $(0.452)$ \\
\hline \multirow[t]{2}{*}{ Size } & $0.241^{* *}$ & $0.441^{* * *}$ & $0.387^{* * *}$ & $0.249^{\star \star}$ & $0.412^{\star \star \star}$ & $0.398^{* * *}$ \\
\hline & $(0.120)$ & $(0.148)$ & $(0.139)$ & $(0.124)$ & $(0.151)$ & $(0.144)$ \\
\hline \multirow[t]{2}{*}{ Arrivals / population } & & $1.726^{* * *}$ & $1.859^{* * *}$ & & $2.103^{* \star *}$ & $2.594^{\star * *}$ \\
\hline & & $(0.262)$ & $(0.269)$ & & $(0.268)$ & $(0.434)$ \\
\hline \multirow[t]{2}{*}{ Small Islands } & & & $-3.231^{* * *}$ & $-1.931^{* *}$ & $-3.388^{\star * *}$ & $-3.680^{* * *}$ \\
\hline & & & $(0.878)$ & $(0.794)$ & $(0.941)$ & $(0.923)$ \\
\hline \multirow[t]{2}{*}{ Receipts / GDP } & & & & $0.404^{\star *}$ & & \\
\hline & & & & $(0.196)$ & & \\
\hline \multirow[t]{2}{*}{ Receipts per tourist } & & & & & $0.463^{* *}$ & \\
\hline & & & & & $(0.206)$ & \\
\hline \multirow[t]{2}{*}{ (Arrivals / population) $^{2}$} & & & & & & $0.119^{* *}$ \\
\hline & & & & & & $(0.056)$ \\
\hline \multirow[t]{2}{*}{ Constant } & $-31.919^{\star \star *}$ & 3.936 & 5.625 & $-20.510^{* *}$ & $21.032^{* *}$ & 4.922 \\
\hline & (8.294) & $(9.622)$ & $(9.641)$ & $(8.645)$ & $(10.458)$ & $(9.648)$ \\
\hline Observations & 794 & 763 & 763 & 775 & 752 & 763 \\
\hline Number of countries & 154 & 152 & 152 & 153 & 151 & 152 \\
\hline
\end{tabular}

Note: Random Effects panel regression using the Hausman-Taylor estimator to correct for the possible correlation of Investment and Tourism with the individual effects $u_{\mathrm{i}}$. Standard errors in parentheses.

Statistical significance at the: ${ }^{* *} 1$ percent level, ${ }^{* *} 5$ percent level, and ${ }^{*} 10$ percent level. 
Table 8. Tourism and Small Islands Interaction Estimations

\begin{tabular}{|c|c|c|}
\hline \multirow{2}{*}{ Variables } & \multicolumn{2}{|c|}{ GDP Growth } \\
\hline & (1) & $(2)$ \\
\hline \multirow[t]{2}{*}{ Convergence } & $-3.750^{\star * *}$ & $-3.885^{* * *}$ \\
\hline & $(0.420)$ & $(0.428)$ \\
\hline \multirow[t]{2}{*}{ Government spending / GDP } & -0.494 & -0.423 \\
\hline & $(0.481)$ & $(0.482)$ \\
\hline \multirow[t]{2}{*}{ Primary education } & 0.896 & 0.839 \\
\hline & $(0.758)$ & $(0.760)$ \\
\hline \multirow[t]{2}{*}{ Openness } & 0.050 & 0.091 \\
\hline & $(0.411)$ & $(0.411)$ \\
\hline \multirow[t]{2}{*}{ Inflation } & $-2.591^{\star \star \star}$ & $-2.629^{* * *}$ \\
\hline & $(0.492)$ & $(0.492)$ \\
\hline \multirow[t]{2}{*}{ Terms of trade } & $0.083^{* * *}$ & $0.083^{* * *}$ \\
\hline & $(0.019)$ & $(0.019)$ \\
\hline \multirow[t]{2}{*}{ Life expectancy } & $4.382^{\star *}$ & $4.416^{\star *}$ \\
\hline & $(2.201)$ & $(2.205)$ \\
\hline \multirow[t]{2}{*}{ Investment / GDP } & 0.684 & $0.746^{*}$ \\
\hline & $(0.446)$ & $(0.446)$ \\
\hline \multirow[t]{2}{*}{ Size } & $0.439^{* * *}$ & $0.421^{* * *}$ \\
\hline & $(0.156)$ & $(0.160)$ \\
\hline \multirow[t]{2}{*}{ Receipts per tourist } & $0.448^{* *}$ & $0.445^{\star *}$ \\
\hline & $(0.207)$ & $(0.207)$ \\
\hline \multirow[t]{2}{*}{ Arrivals / population } & $2.051^{* * *}$ & $2.084^{* * *}$ \\
\hline & $(0.267)$ & $(0.275)$ \\
\hline \multirow[t]{2}{*}{ (Arr. / pop)*Dummy Caribbean } & 0.304 & \\
\hline & $(1.053)$ & \\
\hline \multirow[t]{2}{*}{ Caribbean } & $-3.598^{* * \star}$ & \\
\hline & $(1.323)$ & \\
\hline \multirow[t]{2}{*}{ (Arr. / pop)`Dummy Small Islands } & & 0.386 \\
\hline & & $(0.658)$ \\
\hline \multirow[t]{2}{*}{ Small Islands } & & $-3.033^{* *}$ \\
\hline & & $(1.193)$ \\
\hline \multirow[t]{2}{*}{ Constant } & $20.047^{*}$ & $21.030^{* *}$ \\
\hline & $(10.499)$ & $(10.514)$ \\
\hline Observations & 752 & 752 \\
\hline Number of countries & 151 & 151 \\
\hline \multicolumn{3}{|c|}{$\begin{array}{l}\text { Note: Random Effects panel regression using the Hausman-Taylor } \\
\text { estimator to correct for the possible correlation of Investment and Tourism } \\
\text { with the individual effects } \mathrm{u}_{\mathrm{i}} \text {. Standard errors in parentheses. } \\
\text { Statistical significance at the: }{ }^{* *} 1 \text { percent level, }{ }^{* *} 5 \text { percent level, and }{ }^{*} 10 \\
\text { percent level. }\end{array}$} \\
\hline
\end{tabular}


Table 9. Tourism and Growth Estimations Robustness

\begin{tabular}{|c|c|c|c|c|c|}
\hline \multirow{2}{*}{ Variables } & \multicolumn{5}{|c|}{ GDP Growth } \\
\hline & OLS & $\mathrm{FE}$ & RE & GMM & $\mathrm{HT}$ \\
\hline Convergence & $\begin{array}{l}-1.406^{* * *} \\
(0.222)\end{array}$ & $\begin{array}{c}-5.072^{* * *} \\
(0.610)\end{array}$ & $\begin{array}{c}-1.977^{* * *} \\
(0.286)\end{array}$ & $\begin{array}{l}-1.739 \\
(1.261)\end{array}$ & $\begin{array}{c}-3.801^{* * *} \\
(0.421)\end{array}$ \\
\hline $\begin{array}{l}\text { Government spending / } \\
\text { GDP }\end{array}$ & $\begin{array}{l}-0.433 \\
(0.271)\end{array}$ & $\begin{array}{l}-0.363 \\
(0.645)\end{array}$ & $\begin{array}{l}-0.509 \\
(0.356)\end{array}$ & $\begin{array}{l}1.004 \\
(1.490)\end{array}$ & $\begin{array}{l}-0.419 \\
(0.472)\end{array}$ \\
\hline Primary education & $\begin{array}{l}0.876^{*} \\
(0.507)\end{array}$ & $\begin{array}{c}1.063 \\
(0.893)\end{array}$ & $\begin{array}{l}1.080^{*} \\
(0.634)\end{array}$ & $\begin{array}{c}0.092 \\
(0.851)\end{array}$ & $\begin{array}{c}0.780 \\
(0.751)\end{array}$ \\
\hline Openness & $\begin{array}{l}0.363 \\
(0.238)\end{array}$ & $\begin{array}{c}0.842 \\
(0.546)\end{array}$ & $\begin{array}{l}0.408 \\
(0.309)\end{array}$ & $\begin{array}{l}-0.665 \\
(0.776)\end{array}$ & $\begin{array}{c}0.036 \\
(0.403)\end{array}$ \\
\hline Inflation & $\begin{array}{l}-2.516^{* * *} \\
(0.430)\end{array}$ & $\begin{array}{c}-2.829^{* * *} \\
(0.549)\end{array}$ & $\begin{array}{c}-2.756^{\star * *} \\
(0.455)\end{array}$ & $\begin{array}{c}-2.312^{* * *} \\
(0.721)\end{array}$ & $\begin{array}{c}-2.581^{* * *} \\
(0.491)\end{array}$ \\
\hline Terms of trade & $\begin{array}{l}0.098^{* \star *} \\
(0.021)\end{array}$ & $\begin{array}{l}0.078^{* * *} \\
(0.020)\end{array}$ & $\begin{array}{l}0.089^{* * *} \\
(0.020)\end{array}$ & $\begin{array}{l}0.090^{* * *} \\
(0.032)\end{array}$ & $\begin{array}{l}0.083^{* * *} \\
(0.019)\end{array}$ \\
\hline Life expectancy & $\begin{array}{l}2.873^{* *} \\
(1.392)\end{array}$ & $\begin{array}{l}1.847 \\
(2.493)\end{array}$ & $\begin{array}{l}3.817^{* *} \\
(1.653)\end{array}$ & $\begin{array}{l}-3.767 \\
(4.870)\end{array}$ & $\begin{array}{l}4.417^{* *} \\
(2.200)\end{array}$ \\
\hline Investment / GDP & $\begin{array}{l}1.200^{* * *} \\
(0.253)\end{array}$ & $\begin{array}{c}0.435 \\
(0.478)\end{array}$ & $\begin{array}{l}0.946^{* * *} \\
(0.312)\end{array}$ & $\begin{array}{c}0.494 \\
(1.054)\end{array}$ & $\begin{array}{c}0.728 \\
(0.446)\end{array}$ \\
\hline Size & $\begin{array}{l}0.190^{* * *} \\
(0.063)\end{array}$ & & $\begin{array}{c}0.235^{\star * *} \\
(0.091)\end{array}$ & $\begin{array}{l}0.262 \\
(0.217)\end{array}$ & $\begin{array}{l}0.412^{* * *} \\
(0.151)\end{array}$ \\
\hline Small Islands & $\begin{array}{l}-1.145^{* * *} \\
(0.375)\end{array}$ & & $\begin{array}{c}-1.704^{* * *} \\
(0.552)\end{array}$ & $\begin{array}{l}-2.343^{* *} \\
(0.935)\end{array}$ & $\begin{array}{c}-3.388^{* * *} \\
(0.941)\end{array}$ \\
\hline Arrivals / population & $\begin{array}{l}0.415^{* * *} \\
(0.115)\end{array}$ & $\begin{array}{l}2.312^{* * *} \\
(0.287)\end{array}$ & $\begin{array}{l}0.728^{\star \star *} \\
(0.155)\end{array}$ & $\begin{array}{l}1.729^{* *} \\
(0.704)\end{array}$ & $\begin{array}{l}2.103^{* * *} \\
(0.268)\end{array}$ \\
\hline Receipts per tourist & $\begin{array}{l}0.366^{* *} \\
(0.148)\end{array}$ & $\begin{array}{l}0.457^{* *} \\
(0.220)\end{array}$ & $\begin{array}{l}0.405^{\star \star} \\
(0.171)\end{array}$ & $\begin{array}{c}0.886 \\
(0.583)\end{array}$ & $\begin{array}{l}0.463^{* *} \\
(0.206)\end{array}$ \\
\hline Constant & $\begin{array}{l}-1.435 \\
(5.623)\end{array}$ & $\begin{array}{l}39.084^{* * *} \\
(12.507)\end{array}$ & $\begin{array}{c}0.589 \\
(7.018)\end{array}$ & $\begin{array}{l}42.344^{*} \\
(21.913)\end{array}$ & $\begin{array}{l}21.032^{* *} \\
(10.458)\end{array}$ \\
\hline Observations & 752 & 752 & 752 & 752 & 752 \\
\hline R-squared & 0.220 & 0.282 & & & \\
\hline Number of countries & & 151 & 151 & 151 & 151 \\
\hline
\end{tabular}

Note: Standard errors in parentheses.

Statistical significance at the: ${ }^{* *} 1$ percent level, ${ }^{* *} 5$ percent level, and ${ }^{*} 10$ percent level. 
Table 10. Growth Volatility Estimations

\begin{tabular}{|c|c|c|c|c|c|c|}
\hline \multirow{2}{*}{ Variables } & \multicolumn{6}{|c|}{ Standard Deviation of Growth } \\
\hline & $(1)$ & $(2)$ & $(3)$ & $(4)$ & $(5)$ & $(6)$ \\
\hline Convergence & $\begin{array}{c}0.340 \\
(0.346)\end{array}$ & $\begin{array}{l}1.535^{* * *} \\
(0.370)\end{array}$ & $\begin{array}{l}1.609^{* * *} \\
(0.375)\end{array}$ & $\begin{array}{c}0.348 \\
(0.350)\end{array}$ & $\begin{array}{l}1.842^{* * *} \\
(0.385)\end{array}$ & $\begin{array}{c}1.755^{\star * *} \\
(0.386)\end{array}$ \\
\hline Government spending / & & & & & & \\
\hline GDP & $\begin{array}{l}2.031^{* * *} \\
(0.494)\end{array}$ & $\begin{array}{l}1.556^{* * *} \\
(0.400)\end{array}$ & $\begin{array}{l}1.476^{* * *} \\
(0.398)\end{array}$ & $\begin{array}{l}1.661^{* * *} \\
(0.489)\end{array}$ & $\begin{array}{l}1.570^{* * *} \\
(0.405)\end{array}$ & $\begin{array}{l}1.407^{* * *} \\
(0.402)\end{array}$ \\
\hline Primary education & $\begin{array}{c}-1.574^{* *} \\
(0.775)\end{array}$ & $\begin{array}{c}-1.297^{* *} \\
(0.662)\end{array}$ & $\begin{array}{l}-1.251^{*} \\
(0.658)\end{array}$ & $\begin{array}{l}-1.436^{*} \\
(0.791)\end{array}$ & $\begin{array}{c}-1.675^{\star *} \\
(0.676)\end{array}$ & $\begin{array}{c}-1.539^{* *} \\
(0.683)\end{array}$ \\
\hline Openness & $\begin{array}{l}0.815^{* *} \\
(0.395)\end{array}$ & $\begin{array}{l}1.303^{* * *} \\
(0.356)\end{array}$ & $\begin{array}{l}1.240^{* * *} \\
(0.349)\end{array}$ & $\begin{array}{l}1.063^{* * *} \\
(0.402)\end{array}$ & $\begin{array}{l}1.447^{* * *} \\
(0.357)\end{array}$ & $\begin{array}{c}1.349^{* * *} \\
(0.356)\end{array}$ \\
\hline Inflation & $\begin{array}{c}2.389^{* * *} \\
(0.538)\end{array}$ & $\begin{array}{c}2.233^{* * *} \\
(0.452)\end{array}$ & $\begin{array}{l}2.228^{* * *} \\
(0.451)\end{array}$ & $\begin{array}{l}1.584^{\star * *} \\
(0.538)\end{array}$ & $\begin{array}{l}1.705^{* * *} \\
(0.457)\end{array}$ & $\begin{array}{c}2.252^{* * *} \\
(0.452)\end{array}$ \\
\hline Terms of trade & $\begin{array}{c}-0.069^{* * *} \\
(0.020)\end{array}$ & $\begin{array}{c}0.013 \\
(0.018)\end{array}$ & $\begin{array}{c}0.015 \\
(0.018)\end{array}$ & $\begin{array}{c}-0.078^{* * *} \\
(0.021)\end{array}$ & $\begin{array}{c}0.008 \\
(0.018)\end{array}$ & $\begin{array}{c}0.012 \\
(0.018)\end{array}$ \\
\hline Life expectancy & $\begin{array}{c}-11.994^{* * *} \\
(2.441)\end{array}$ & $\begin{array}{c}-8.904^{* * *} \\
(2.103)\end{array}$ & $\begin{array}{c}-8.814^{* * *} \\
(2.099)\end{array}$ & $\begin{array}{c}-11.080^{* * *} \\
(2.385)\end{array}$ & $\begin{array}{c}-7.228^{\star * *} \\
(2.068)\end{array}$ & $\begin{array}{c}-9.170^{* * *} \\
(2.114)\end{array}$ \\
\hline Investment / GDP & $\begin{array}{c}2.490^{* * *} \\
(0.484)\end{array}$ & $\begin{array}{l}1.124^{* * *} \\
(0.433)\end{array}$ & $\begin{array}{l}1.086^{* *} \\
(0.433)\end{array}$ & $\begin{array}{l}1.666^{\star * *} \\
(0.496)\end{array}$ & $\begin{array}{c}0.820^{*} \\
(0.426)\end{array}$ & $\begin{array}{l}1.035^{* *} \\
(0.435)\end{array}$ \\
\hline Size & $\begin{array}{l}-0.056 \\
(0.145)\end{array}$ & $\begin{array}{l}-0.171 \\
(0.114)\end{array}$ & $\begin{array}{l}-0.154 \\
(0.111)\end{array}$ & $\begin{array}{l}-0.118 \\
(0.142)\end{array}$ & $\begin{array}{l}-0.125 \\
(0.116)\end{array}$ & $\begin{array}{l}-0.159 \\
(0.112)\end{array}$ \\
\hline Arrivals / population & & $\begin{array}{c}-0.960^{\star * *} \\
(0.249)\end{array}$ & $\begin{array}{c}-1.032^{* * *} \\
(0.258)\end{array}$ & & $\begin{array}{c}-1.125^{\star * *} \\
(0.256)\end{array}$ & $\begin{array}{c}-1.551^{* * *} \\
(0.417)\end{array}$ \\
\hline Small Islands & & & $\begin{array}{l}1.401^{*} \\
(0.717)\end{array}$ & $\begin{array}{c}1.020 \\
(0.898)\end{array}$ & $\begin{array}{l}1.891^{* *} \\
(0.740)\end{array}$ & $\begin{array}{l}1.712^{* *} \\
(0.745)\end{array}$ \\
\hline Receipts / GDP & & & & $\begin{array}{c}-0.768^{* * *} \\
(0.202)\end{array}$ & & \\
\hline Receipts per tourist & & & & & $\begin{array}{c}-0.892^{* * *} \\
(0.196)\end{array}$ & \\
\hline (Arrivals / population) $^{2}$ & & & & & & $\begin{array}{l}-0.085 \\
(0.054)\end{array}$ \\
\hline Constant & $\begin{array}{c}41.771^{\star \star *} \\
(8.761)\end{array}$ & $\begin{array}{c}18.084^{* *} \\
(9.112)\end{array}$ & $\begin{array}{l}17.085^{*} \\
(9.150)\end{array}$ & $\begin{array}{c}36.507^{\star * *} \\
(9.050)\end{array}$ & $\begin{array}{c}2.845 \\
(9.851)\end{array}$ & $\begin{array}{c}18.020^{* *} \\
(9.183)\end{array}$ \\
\hline Observations & 794 & 763 & 763 & 775 & 752 & 763 \\
\hline Number of countries & 154 & 152 & 152 & 153 & 151 & 152 \\
\hline
\end{tabular}

Note: Random Effects panel regression using the Hausman-Taylor estimator to correct for the possible correlation of Investment and Tourism with the individual effects $u_{i}$. Standard errors in parentheses.

Statistical significance at the: ${ }^{* *} 1$ percent level, ${ }^{* *} 5$ percent level, and ${ }^{*} 10$ percent level. 
Table 11. Growth Accounting Estimations

\begin{tabular}{|c|c|c|c|}
\hline \multirow{2}{*}{ Variables } & \multicolumn{3}{|c|}{ Growth of } \\
\hline & Output per worker & Capital per worker & TFP \\
\hline \multirow[t]{2}{*}{ Convergence } & $-4.165^{\star * *}$ & $-3.946^{* * *}$ & $-5.890^{* * *}$ \\
\hline & $(0.415)$ & $(0.429)$ & $(0.552)$ \\
\hline \multirow[t]{2}{*}{ Government spending / GDP } & -0.684 & 0.209 & -0.509 \\
\hline & $(0.474)$ & $(0.703)$ & $(0.487)$ \\
\hline \multirow[t]{2}{*}{ Primary education } & 0.838 & 1.111 & 0.508 \\
\hline & $(0.734)$ & $(1.033)$ & $(0.749)$ \\
\hline \multirow[t]{2}{*}{ Openness } & 0.088 & $1.631^{\star * *}$ & -0.505 \\
\hline & $(0.396)$ & $(0.580)$ & $(0.402)$ \\
\hline \multirow[t]{2}{*}{ Inflation } & $-2.577^{\star \star \star}$ & 0.629 & $-2.479^{\star \star *}$ \\
\hline & $(0.478)$ & $(0.656)$ & $(0.496)$ \\
\hline \multirow[t]{2}{*}{ Terms of trade } & $0.081^{* * *}$ & 0.005 & $0.079^{\star \star *}$ \\
\hline & $(0.019)$ & $(0.025)$ & $(0.020)$ \\
\hline \multirow[t]{2}{*}{ Life expectancy } & $3.670^{*}$ & -4.663 & $4.485^{\star \star}$ \\
\hline & $(2.114)$ & (2.919) & $(2.162)$ \\
\hline \multirow[t]{2}{*}{ Size } & $0.404^{* *}$ & $0.815^{\star *}$ & 0.127 \\
\hline & $(0.157)$ & $(0.332)$ & $(0.142)$ \\
\hline \multirow[t]{2}{*}{ Small Islands } & $-3.025^{\star * *}$ & -0.870 & $-3.526^{* * *}$ \\
\hline & $(0.962)$ & $(1.955)$ & $(0.907)$ \\
\hline \multirow[t]{2}{*}{ Arrivals / population } & $2.078^{* * *}$ & $2.250^{* \star \star}$ & $1.743^{* * *}$ \\
\hline & $(0.253)$ & $(0.310)$ & $(0.266)$ \\
\hline \multirow[t]{2}{*}{ Receipts per tourist } & $0.389^{\star *}$ & $0.551^{* *}$ & 0.340 \\
\hline & $(0.197)$ & $(0.260)$ & $(0.208)$ \\
\hline \multirow[t]{2}{*}{ Constant } & $30.116^{* * *}$ & $55.907^{* * *}$ & $24.300^{* *}$ \\
\hline & $(10.355)$ & $(13.351)$ & (11.023) \\
\hline Observations & 751 & 751 & 751 \\
\hline Number of countries & 151 & 151 & 151 \\
\hline
\end{tabular}

Note: Random Effects panel regression using the Hausman-Taylor estimator to correct for the possible correlation of Investment and Tourism with the individual effects $u_{i}$. Standard errors in parentheses. Statistical significance at the: ${ }^{* *} 1$ percent level, ${ }^{* *} 5$ percent level, and ${ }^{*} 10$ percent level. 
Table 12. List of Countries

\begin{tabular}{|c|c|c|}
\hline Algeria & Egypt & Lithuania \\
\hline Angola & EI Salvador & Macedonia, Republic of \\
\hline Argentina & Equatorial Guinea & Madagascar \\
\hline Australia & Estonia & Malawi \\
\hline Austria & Ethiopia & Malaysia \\
\hline Azerbaijan & Finland & Maldives \\
\hline Bahamas, The & France & Mali \\
\hline Bahrain & Gabon & Malta \\
\hline Bangladesh & Gambia, The & Mauritania \\
\hline Barbados & Georgia & Mauritius \\
\hline Belarus & Germany & Mexico \\
\hline Belgium & Ghana & Moldova \\
\hline Belize & Greece & Mongolia \\
\hline Benin & Grenada & Morocco \\
\hline Bhutan & Guatemala & Mozambique \\
\hline Bolivia & Guinea-Bissau & Namibia \\
\hline Botswana & Guyana & Nepal \\
\hline Brazil & Haiti & Netherlands \\
\hline Bulgaria & Honduras & New Zealand \\
\hline Burkina Faso & Hong Kong SAR & Nicaragua \\
\hline Burundi & Hungary & Niger \\
\hline Cambodia & Iceland & Nigeria \\
\hline Cameroon & India & Norway \\
\hline Canada & Indonesia & Oman \\
\hline Cape Verde & Iran, Islamic Republic of & Pakistan \\
\hline Central African Republic & Ireland & Panama \\
\hline Chad & Israel & Papua New Guinea \\
\hline Chile & Italy & Paraguay \\
\hline China & Jamaica & Peru \\
\hline Colombia & Japan & Philippines \\
\hline Congo, Dem. Rep. of & Jordan & Poland \\
\hline Congo, Rep. of & Kazakhstan & Portugal \\
\hline Costa Rica & Kenya & Qatar \\
\hline Côte d'Ivoire & Korea, Republic of & República Bolivariana de Venezuela \\
\hline Croatia & Kuwait & Romania \\
\hline Cyprus & Kyrgyz Republic & Russian Federation \\
\hline Czech Republic & Lao People's Democratic Republic & Rwanda \\
\hline Denmark & Latvia & Samoa \\
\hline Dominica & Lebanon & Saudi Arabia \\
\hline Dominican Republic & Lesotho & Senegal \\
\hline Ecuador & Libya & Seychelles \\
\hline Sierra Leone & Sudan & Turkey \\
\hline Singapore & Suriname & Uganda \\
\hline Slovak Republic & Swaziland & Ukraine \\
\hline Slovenia & Sweden & United Kingdom \\
\hline Solomon Islands & Switzerland & United States \\
\hline South Africa & Syrian Arab Republic & Uruguay \\
\hline Spain & Tanzania & Vanuatu \\
\hline Sri Lanka & Thailand & Vietnam \\
\hline St. Kitts and Nevis & Togo & Zambia \\
\hline St. Lucia & Trinidad and Tobago & \\
\hline St. Vincent and the Grenadines & Tunisia & \\
\hline
\end{tabular}

